Florida International University FIU Digital Commons

6-25-2014

\title{
Alienated Selfhood and Heroism: A Poststructuralist Reading of John le Carrés Spy Fiction Novels
}

Milton Zuniga

Florida International University, mlzun@netscape.net

DOI: $10.25148 /$ etd.FI14071175

Follow this and additional works at: https://digitalcommons.fiu.edu/etd

\section{Recommended Citation}

Zuniga, Milton, "Alienated Selfhood and Heroism: A Poststructuralist Reading of John le Carrés Spy Fiction Novels" (2014). FIU Electronic Theses and Dissertations. 1541.

https://digitalcommons.fiu.edu/etd/1541 


\section{FLORIDA INTERNATIONAL UNIVERSITY}

Miami, Florida

\section{ALIENATED SELFHOOD AND HEROISM: A POST-STRUCTURALIST READING OF JOHN LE CARRÉ'S SPY FICTION NOVELS}

A thesis submitted in partial fulfillment of the

requirements for the degree of

MASTER OF ARTS

in

ENGLISH

by

Milton Zuniga

2014 
To: Interim Dean Michael R. Heithaus

College of Arts and Sciences

This thesis, written by Milton Zuniga, and entitled Alienated Selfhood and Heroism: A Poststructuralist Reading of John le Carré's Spy Fiction Novels, having been approved in respect to style and intellectual content, is referred to you for judgment.

We have read this dissertation and recommend that it be approved.

Nathaniel Cadle

Richard Sugg

Bruce Harvey, Major Professor

Date of Defense: June 25, 2014

The thesis of Milton Zuniga is approved.

Interim Dean Michael R. Heithaus

College of Arts and Sciences

Dean Lakshmi N. Reddi

University Graduate Studies

Florida International University, 2014 
(C) Copyright 2014 by Milton Zuniga

All rights reserved. 


\section{ACKNOWLEDGMENTS}

I wish to thank the members of my committee for their patience, understanding, and intellectual support. Their direct and firm guidance has made this project a reality. Dr. Nathaniel Cadle, thank you for taking the time to show me that writing is not just about putting words on paper. Dr. Richard Sugg, thank you for always being the voice of encouragement and support. Dr. Bruce Harvey, I wish to truly thank you for taking on the responsibility of helping me, an unknown student to you at the time, by agreeing to be my Major Professor in this project, and for not letting me settle for less than what I can do. Finally, I want to express my sincere gratitude to Dr. Asher Milbauer who was always available and willing to help me move along with my goals. To all, my most sincere appreciation.

I have found my coursework throughout the English program to be challenging and stimulating while providing me the tools and experience necessary to explore other opportunities in my field of choice. 
ABSTRACT OF THE THESIS

\title{
ALIENATED SELFHOOD AND HEROISM: A POST-STRUCTURALIST READING OF JOHN LE CARRÉ'S SPY FICTION NOVELS
}

\author{
by \\ Milton Zuniga \\ Florida International University, 2014 \\ Miami, Florida \\ Professor Bruce Harvey, Major Professor
}

John le Carré's novels “The Spy Who Came in From the Cold” (1963), “Tinker, Tailor, Soldier, Spy” (1974), and “The Tailor of Panama” (1997), focus on how the main characters reflect the somber reality of working in the British intelligence service. Through a broad post-structuralist analysis, I will identify the dichotomies - good/evil in “The Spy Who Came in From the Cold,” past/future in “Tinker, Tailor, Soldier, Spy,” and institution/individual in "The Tailor of Panama" - that frame the role of the protagonists. Each character is defined by his ambiguity and swinging moral compass, transforming him into a hybrid creation of morality and adaptability during transitional time periods in history, mainly during the Cold War. Le Carré's novels reject the notion of spies standing above a group being celebrated. Instead, he portrays spies as characters who trade off individualism and social belonging for a false sense of heroism, loneliness, and even death. 


\section{TABLE OF CONTENTS}

CHAPTER

PAGE

I. CONSTRUCTING SHADOWS AND ILLUSIONS $\ldots \ldots \ldots \ldots \ldots \ldots \ldots \ldots \ldots \ldots$

II. FALLING SHORT OF REDEMPTION ..................................13

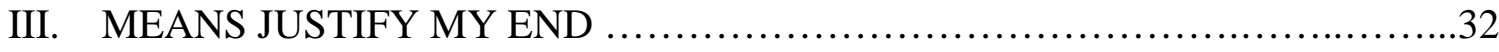

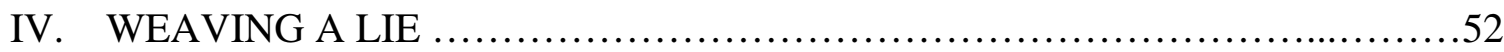

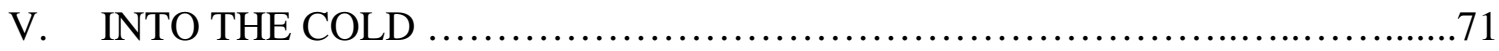

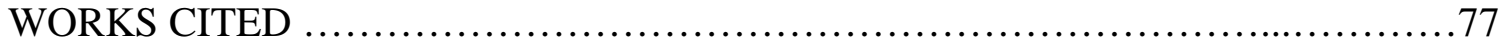




\section{CONSTRUCTING SHADOWS AND ILLUSIONS}

John le Carré's spy novels The Spy Who Came in From the Cold (1963), Tinker, Tailor, Soldier, Spy (1974), and The Tailor of Panama (1997), focus on the struggles the protagonists have as spies. ${ }^{1}$ The novels display characters who are submerging their individuality to pursue dubiously patriotic yet clandestine goals, the former which undermines initial or sustained realism, the latter which dissociates them from any community other than the secretive and murky agencies they either affiliate with or fight against. Upon a closer reading of the novels, the spy is revealed as flawed and isolated from society, which allows Le Carré the opportunity to undermine any heroic pursuit by the individual. In the three novels to be examined in this thesis, Le Carré hinders his main characters' chances at heroism, and instead shapes them to be social outcasts in need of salvation and redemption. ${ }^{2}$ With an undertone of resentment, in addition to textual hierarchies, and aporai, ${ }^{3}$ Le Carré exposes the insulated world of spies and the 'cold' environment in which secrets are shared. ${ }^{4}$

${ }^{1}$ Tinker, Tailor, Soldier, Spy (1974) is the first part of the "The Karla Trilogy" along with The Honourable Schoolboy (1977), and Smiley's People (1980). The trilogy helps to establish familiar themes in subsequent texts by John le Carré. These include loyalty/betrayal, past/present, and institution/individualism. The trilogy traces George Smiley's pursuit and eventual reunion with his “darker half,” Soviet spymaster Karla. The trilogy would be reissued in 1982 under the name The Quest for Karla (Beene 89).

${ }^{2}$ Born David John Moore Cornwell, he adopted the penname of "John le Carré" while working at MI-6, the British military intelligence version of the CIA. As an agent, he was not allowed to publish documents or manuscripts under his real name. "Le Carré" is French for "the square" or "straightforward," but it can also signify "a whimsically tied fabric that hides an unsightly chair" (Beene 146).

\footnotetext{
${ }^{3}$ According to Derrida, aporia is "the difficult or the impracticable [...] passage which can in fact be something else [...] which no longer has the form of the movement that consist in passing; the 'coming to pass'” (Derrida, Aporias 8).

${ }^{4}$ The cold is a reference to the place where spies operate. In particular, it refers to working behind enemy lines or in places where their life is at risk or operational outcomes are be compromised.
} 
John le Carré was an active intelligence officer during the Cold War and utilizes The Spy Who Came in From the Cold to loosely narrate his rather negative experiences while in the service. ${ }^{5}$ Therefore, the novel marks "the last book of his period of innocence” (Le Carré, The Spy Who Came in From the Cold ix) ${ }^{6}$. As with The Spy Who Came in From the Cold, in his other novels, Le Carré attempts to vindicate his characters' morals and deem their actions as necessary in order to preserve peace. As an author, he also attempts to justify the morals of his characters in order to create an identity for each one, and at times, exonerates their actions in an effort to depict their flaws as consequences of espionage, and not as character flaws. Ultimately, every protagonist Le Carré creates - Alec Leamas in "The Spy Who Came in From the Cold," George Smiley in “Tinker, Tailor, Soldier, Spy,” and Andy Osnard in "The Tailor of Panama” - cannot exist outside of espionage as regular citizens.

As individuals, the characters have their own sets of problems and personal demons to confront. Each has failure in his personal past or the death of another intelligence agent under his supervision. In the three novels, the main character finds himself at the end of his service, or on the "shelf," struggling to reconstruct his identity and individuality. However, the characters are ultimately recalled into the intelligence service in order to complete one last mission that will allow them the opportunity to cement their patriotism and salvage legacy within the British intelligence agency.

\footnotetext{
${ }^{5}$ Le Carré's detailed participation in the British intelligence service remains a mystery. His autobiography only mentions his involvement in the service as an analyst and support personnel. There is no mention of him being an actual spy, and neither Le Carré nor his biographer confirm or deny his role in the service (Cobbs 7).

${ }^{6}$ Prior to The Spy Who Came in From the Cold, Le Carré wrote "inside the walls of the secret world, under another name, and free of serious critical attention. Once this book hit the stands, my time of quiet and gradual development was over for good” (Le Carré, The Spy Who Came in From the Cold ix).
} 
Oftentimes, spies are recalled under the pretense of preserving peace, the integrity of the institution, or to prevent international chaos. However, a spy's final mission often isolates him further isolated from society, revisiting past errors, or gets killed in their last effort in trying to attain redemption for their past mistakes. Based on personal experience, as Le Carré points out, the difficulties for spies lie in the challenging nature of their work. "I know I was deeply unhappy in my professional life, and that I was enduring the extremes of loneliness and personal confusion” (Le Carré, The Spy Who Came in From the Cold, xi).

Having been an intelligence officer, John le Carré uses writing to depict a truthful and inglorious vision of espionage. He creates scenarios based on historical conflicts that challenge the accepted notion of Western democracy and the spread of Communism across Russia and Eastern Europe. In his novels, the characters live in a gray world instead of the clear, black and white world of other notable spies in literature, especially James Bond. Characters such as Bond are normally depicted through archetypal qualities and primarily function to draw the audience into an idealistic reality which showcases the fantastic possibilities of espionage. Bond, especially, is a character driven by deep patriotic purpose clearly understood by the audience. ${ }^{7}$ Unlike the characters created by Le Carré, Bond embraces the glory and romanticism of espionage. He stands out from the crowd and avoids prolonging his stay in the 'cold' environment, the debilitating habits, and the pathetic characters washed out by the profession. Bond also provides a glimpse, albeit idealistic, and a romantic view into a world of secrets and dealings that often

\footnotetext{
${ }^{7}$ James Bond follows the archetypal model of the traditional hero. The audience welcomed him and expects him to succeed in his labors regardless of the condition, conflicts, or enemies he may encounter throughout his journey.
} 
characterize the true work of the spy. But Le Carré's novels are aimed at portraying a different version of the spy's reality, "a corrective antidote and the creation of a realistic spy” (Cobbs 46). The nature, the purpose, and the ideological foundation of espionage Le Carré builds is based on his experiences and understanding of the paradigms of espionage. According to Le Carré, espionage is a necessary evil that utilizes a character like James Bond to illustrate the plausibility of the profession. However, the characters he chooses to create, Smiley, Leamas, and Osnard who portray a more realistic vision of the perils involved with espionage.

In contrast to James Bond who embraces the mystique and glory of espionage, the characters in "The Spy Who Came in From the Cold”, “Tinker, Tailor, Soldier, Spy,” and “The Tailor of Panama," are destined to live in isolation. Each character analyzed in this thesis alienates himself to survive and to protect others from falling into his same tragic path. The spies also set themselves apart from the rest of society because the rules of the common people no longer apply to them. They have learned to exist in the world of secrets and shadows where identities are lost along with morals and loyalty. This allows spies to live in two worlds: one without directive or reward, where their identities remain a mystery to everyone, and the world in which they operate, which offers no moral or ethical guidelines, nor virtues of truth needed to function. Therefore, by having to inhabit one world and operate in another, the spy always hesitates between the abstract and the material, between truth and the illusion of truth (Beene 26). This constant struggle to fit into an environment with comfort and relative safety creates individuals that are at odd with themselves; therefore, blurring their professional purposes and redirecting their lives 
and existences toward unifying their being. Most often, that search for personal stability ends in disappointment or death.

For spies, the struggle to adjust to two worlds can lead to alienation. This isolation occurs when the spy, willingly and at times unknowingly, sets himself apart from society and its religious and social institutions, including the intelligence agency that employs him. This self-imposed exile further alienates the spy because it falsely leads him to believe that his knowledge, skills, and the information he possesses can alter the course of history. Ultimately, this false-authority rationale for isolation damages the individual because it creates a fabricated sense of superiority and of "being above the course of history and compulsion of dialectic” (Le Carré, The Spy Who Came in From the Cold, 190). By isolating himself, the spy creates a make-belief existence beyond the boundaries of normal society where he can become a self-centered and greedy individual. When analyzing the novels, it can be concluded that the individual's alienation is the result of moral attitudes which he approaches intellectually, but not emotionally. In the novels, Le Carré narrates and describes scenarios that illustrate how intellectual commitment, without emotional attachments, disengages the individual, leaving him vulnerable and open to the possibility of committing treason. In fact, "Le Carré creates largely convincing characters whose often unshakeable faith in conspiracy leads them uncontrollably to treachery” (Beene 15). Espionage in particular, is an intellectual pursuit born out of the necessity for information and secrets. However, secrets are tools, and information is a currency for deceit, safety, national and transnational interests.

Inevitably, secrets can become assets and commodities that benefit of the individual spy. 
It is the nature of the trade to exchange information and create a secret economy of favors and blackmail, extortion and lies with the intention of elevating national interests. For the spy, the enterprise of international secrets also becomes an opportunity to aggrandize the self.

Historically, characters in spy novels are created in a murky world, oftentimes a darker, more sinister vision of what society chooses to accept, therefore, the characters and conflicts in spy novels can be derived more from fiction and myth than from concrete struggles in the political realm. The modern spy novel and modern espionage genre which derives from the works of writers like Robert E. Childers, Rudyard Kipling, Joseph Conrad, W. Somerset Maugham, Alexander Wilson and Leslie Charteris, was born out of mutual suspicion between Britain, Russia, and Germany in the early part of the twentieth century (Fletcher 322) ${ }^{8}$. Prior to World War I, Britain feared the growing strength of the German navy, while Germany feared an unprovoked British invasion. These unfounded fears, social and collective paranoia compounded by mutual suspicion led to the creation of the modern intelligence bureaucracy and to the birth of the modern spy in all his imaginative forms. To further fuel the notion of security and need of centralized awareness of suspicious states, fiction writers, driven by imagination and overly-patriotic sensibility, exploited the political turbulence of the time and attempted to capture the exploits of those involved (Beene 27). Prior to the release of "The Spy Who Came in From the Cold” in 1963, Ian Fleming, Graham Greene, and Eric Ambler were among the few serious writers of spy thrillers considered more than entertainment. Fleming’s James

\footnotetext{
${ }^{8}$ The term "spy novel” was defined by Robert E. Childers in his novel Riddle of the Sands (1903) in which amateur spies discover a German plan to invade Britain. The novel's plot of suspicion and possible invasion opened the door for other writers to imitate and expand on the idea (Sauerberg 19).
} 
Bond, Greene’s “Stamboul Train” (1932) on which the film “Orient Express” (1934) was based, and Ambler’s “The October Man” (1947), which introduced a new sense of realism to the genre, became the founding pillars for the modern spy novels and political dramas (Cobbs 46). Greene, a contender for the Nobel Prize, had written only a handful of spy novels, and upon closer examination, his work proved highly fictionalized and farflung from realistic merits. Ambler, however, had written only spy thrillers "but his best work was now in the past” (Cobb 44). These authors and their characters' exploits oftentimes helped spread political sentimentalism and further grow trust in spy agencies. As the mystique of espionage grew, so did the popular interest in fiction spy novels as well the re-imaginative figure of the spy as a main character. This positioned Le Carré to rival Fleming in the ever-popular spy thriller genre of the 1940s - 1970s. However, with Fleming’s death the following year in 1964, Le Carré was virtually unchallenged.

By the time Le Carré began writing, the fictional spy had become a fascinating character with the perpetuation of the Bond books after Ian Fleming's death in 1964. Undoubtedly, Le Carré’s success was fueled by Fleming’s spectacular popularity along with the "Cold Warrior charisma of John F. Kennedy, the Cuban missile crisis, and the social and economic success of West Germany” (Cobbs 45). Throughout the history of spy fiction, the primary factor that motivated the individual to commit espionage was ideology and the search for truth in a world of shadows and political ploys unfamiliar to 
the greater population. ${ }^{9}$ The spy typically followed a belief system that structured and defined the moral boundaries of the first-world versus those engulfed in the grip of Communism and oppression. For society, spies had become the ideological liberators, the infiltrators that could help entire countries find their path toward social freedom, democracy, and ultimately, integration into the developing world that was leaving behind the scars of World War II. This ideology also motivated the enemy of the democratic states, most notably Russia, whose spy agency - the Committee for State Security, or KGB for its name in Russian - with its army of spies ready to spill blood for their imperial cause, became an emphatic symbol of extreme ideological zeal. After the height of the Cold War, from 1953 to 1962, the ideological foundation for espionage slowly began to recede and make way for other motivational factors. ${ }^{10}$ For spies, ideology towards country and duty were shifting. Money, revenge, ego, fame, and thrill, among other more personal motives, soon became the primary motivators for spies. They became followers of ideals and personal interests that contradicted established conventions of a career designed to covertly serve the greater good.

At this time, the ideological roots a spy had stood for became symbols of a country’s path toward national glory. Communism and capitalism became divergent

\footnotetext{
${ }^{9}$ Articles commissioned by the United States military and intelligence community point to a series of character flaws that develop throughout a career in the clandestine service. These may include, but are not limited to antisocial behavior, narcissism, impulsiveness, inability to form a commitment, vindictiveness, paranoia, and risk-seeking. These conditions can appear in the profile of a spy as a result of internal conflicts between duties and ideals (Behavior Patterns and Personality Characteristics Associated with Espionage).

${ }^{10}$ The decade between the death of Russian leader Joseph Stalin and the Cuban Missile Crisis (1953 1962) is regarded as the height of the Cold War. During this period, communism and Russian influence expanded from Eastern Europe to China and Cuba, a country that underwent its own revolution in 1959 and adopted a Marxist-Leninist ideology setting up the first communist country in the Western hemisphere (Cobbs 16).
} 
views in the evolution of freedom and justice. In Graham Greene's novels such The Heart of the Matter (1948) where he "explores the morality of espionage in a left-leaning, anti-imperialist," Our Man in Havana (1959) which explores the Communist revolution in Cuba, and Len Dighton's The IPCRESS File with an anonymous spy all helped institute an anti-Establishment sentiment in the spy fiction genre (Cobbs 61). These Cold War- era novels started to imitate the reality of espionage where country and servicemen parted ways from their common goal and followed what each thought was best for them. Espionage was now a symbiotic relationship between spy and agency where the spy may have had an individual mindset or set of goals different from those of an agency. For British spy characters, personal motivation, a loss of trust in their mission and philosophy, along with the emergence of the "mole" - a term Le Carré borrowed from the KGB indicative of spies implanted deep undercover in foreign organization - and dissatisfaction with the job became debilitating factors for the Circus (Le Carré, Conversations with John Le Carré 33-34). ${ }^{11}$ It also defined a new reality for the British spy. ${ }^{12}$

Considering the tension in the texts between individuals, organizations, and personal ideology, in this thesis, post-structuralism will be implemented as a method of examining the tensions as binary oppositions, or hierarchies in each novel. The main opposition found within the novels are: good/evil in "The Spy Who Came in From the Cold,” past/future in “Tinker, Tailor, Soldier, Spy,” and institution/individual in “The

\footnotetext{
${ }^{11}$ The Circus is the nickname used by British intelligence officers when referring to the Secret Service Bureau headquarters, the forerunner of the military Secret Intelligence Service, or MI - 6 (Beene 17).

12 This new reality was defined not by nationalism or spy loyalty, but by secret-sharing and doubleespionage at times for allies, and sometimes for competing nations.
} 
Tailor of Panama.” In "The Spy Who Came in From the Cold,” Alec Leamas and the Circus represent emblems of Western democracy while Hans-Dieter Mundt and the Party as symbols of Communism and Russian influence in global politics. George Smiley, in “Tinker, Tailor, Soldier, Spy,” is a man who must face the past in order to save the future of British espionage. In "The Tailor of Panama” the needs of the Circus as an institution versus the individual needs of Andrew Osnard will be the basis for conflict. In each chapter, using a broad post-structuralist approach and textual evidence, I will analyze the hierarchical placement of each element and how each novel elevates or diminishes their positioning within the dichotomy. I will place privileged elements from each novel under erasure to determine instabilities in logical support provided by that novel. Lastly, I will arrive at a conclusion of how the elements in the novels form symbiotic relations needed to structurally support the text. And finally, I will examine the elements such as characters and situations within the novels that are excluded, and how these could allow the text to interpreted differently. In this thesis, the three novels will be presented in an order that follows the spy as he confronts the personal struggles in "The Spy Who Came in From the Cold.” Then, I will discuss how a spy agency can also suffer from institutional challenges in “Tinker, Tailor, Soldier, Spy.” I will conclude my analysis by examining how in "The Tailor of Panama” Le Carré presents a truer sense of espionage as a whole - or at least how the author wants the audience to envision it.

“The Spy Who Came in From the Cold" (1963) is a careful examination and criticism of the ideological elements that destabilized the world during the Cold War. In this novel, Le Carré attempts to examine the internal struggles that spies must deal with 
on a daily basis. The intricacy of Le Carré's symbols, characters, the choices spies make, and the vague attempt at humanism inspire in the reader a powerful fascination with the genre, and a profound sense of pity toward the individual spy. The novel presents Alec Leamas as a dramatic example of a spy who has dedicated himself to his profession yet has nothing to show for his sacrifices. He is a lonely man, accompanied by sorrow, anger and the constant bitterness of an unfulfilled life. But more importantly, in "The Spy Who Came in From the Cold,” Le Carré captures the ruthless and chaotic world of espionage and immerses the reader into the 'cold,' where along with the spy, witnesses the danger and damaging effects of the profession. Ultimately, the reader understands that spies are in need of salvation, particularly when Alec Leamas chooses death over a continued life of loneliness, betrayal, and lies.

“Tinker, Tailor, Soldier, Spy” (1974) brings George Smiley to the forefront of John Le Carré’s spy fiction. He is a complex character who has served as Le Carré’s moral compass to the ills of espionage. Sometimes a minor character, other times a heroic man, and always a faithful spy to the cause, Smiley is now the unheroic, timid secret agent in charge of restoring credibility to the Circus. In order to achieve his goal, he must first cleanse the Circus of a mole, for the safety of his coworkers, the principles of the institution, and to redeem his legacy. With Smiley, as complex a character as Le Carré has created, "the dramatic and sociological possibilities of such a hero are considerable” (Locke). In this novel, Le Carré moves beyond the individual and into the collective challenges of the spy agency. Through intricate narrative and memorable characters, he transitions from the struggles of the individual and into the challenges faced by spy 
agencies. Le Carré also uses Smiley as a way of exposing the flaws of espionage instead of using him to directly criticize the Establishment, even though Smiley provides Le Carré the avenue to do so. In the end, one finds that the "good guys," the spies like Smiley, are alone in a world where betrayal is common and the code of honor and service to country and the Crown are mantras that only serve to hide the dark truth and selfishness of man and spy.

“The Tailor of Panama” (1997) begins as a comic rarity given the form and depth normally associated with Le Carré's novels. However, one quickly realizes that this Shakespeanesque comedy turns into a bizarre, darker immersion into the inner workings of the mind of a washed-out spy. Le Carré attempts redemption for characters whose lives have been marked by a series of bad choices, but unfortunately, almost in a morally cannibalistic way, redemption for one man can only come at the expense of another man’s fall. Through this intricate moral maze woven by a respectable tailor, a superfluous spy, and a traumatized country, Le Carré leads the reader on a quest to find the answers to an enigmatic question: can a spy ever be redeemed? 


\section{FALLING SHORT OF REDEMPTION}

“The Spy Who Came in From the Cold” (1963) establishes John le Carré as a prominent spy fiction writer. Prior to this novel, Le Carré had written two other mystery fiction novels, Call for the Dead (1961) and “A Murder of Quality” (1962), both of which reflected a personal motive rather than a political one. With his third novel, "The Spy Who Came in From the Cold," Le Carré was able to connect with his audience, and humanize the tribulations and schemes of spies, while demystifying the most complex political plots (Tyler 13). By making the spy examine his position within the state and evaluate his belief system, Le Carré in turn elicits a moral reaction from the reader. Furthermore, the conflicts identified in the text deal with the ideological approach each spy or spy agency undertakes toward achieving their goal and upholding their philosophy. The Circus, the common name used when referring to the British Intelligence Service, defends its actions as necessary in order to prevent the spread of Communism by portraying it as an ideology that corrupts entire countries. For Communism, the mission of spreading throughout Eastern Europe is ongoing and demands personal sacrifice. The Circus, throughout the text, is portrayed as an efficient entity in charge of gathering intelligence and neutralizing possible threats towards the safety of England and the Western world at large. "The Spy Who Came in From the Cold” also gives Le Carré an opening to explore themes that he eventually carries over to his later work, and allows him the opportunity to redefine the spy fiction genre.

"The Spy Who Came in From the Cold" opens with the death of Karl Riemeck, a young British intelligence agent, trying to cross to West Germany. He was the last 
survivor of the Berlin station run by Alec Leamas. As the chief of station, Leamas is recalled to the Circus where Control, a codename for the British spymaster, asks him to "stay out in the cold a little longer" and carry out one last mission: to infiltrate East Germany’s Intelligence service with the goal of discrediting its chief, Hans Dieter Mundt (Le Carré, The Spy Who Came in From the Cold 15). After a series of struggles with a dull, low-paying job at a library where he meets Liz, a young Communist party member, and a brief stay in prison resulting from a drunken rage, Leamas lets himself be recruited by Communist Germany agents and relocates to Holland. He is well-compensated financially and debriefed on British intelligence networks in and around Europe. While in Holland, Leamas is interrogated by Fiedler, Mundt's deputy, who is already suspicious of Mundt's loyalty and goal. He then plans to use Leamas to expose Mundt as a traitor. In the meantime, Liz is persuaded to attend a Communist conference where she will eventually be captured and taken to a secret trial to testify against Leamas. In speaking to Fiedler, Leamas soon realizes the whole operation has been planned by Control, and quickly realizes that Mundt is a British intelligence agent. With this new knowledge, Leamas must now escape from East Germany to avoid detection and probable death. Because of Leamas's connection with Liz, Mundt arranges for both to leave East Germany via Berlin. He gives Leamas precise instructions on how to cross over the Wall into West Berlin, however, both Leamas and Liz are shot dead as they attempt to cross from East Germany.

In Le Carré's novels, a spy is an individual who wanders the world amid the shadows of the past and the sins committed while under cover. In "The Spy Who Came 
in From the Cold," alienation of the individual is a direct result of the strains imposed by the job of spying. Le Carré admits that a man who plays a role, to others and for the matter of deception, is always in psychological danger. "But while actors, illusionists, and those who portray a deviation of reality can always come back to the real world and the comforts of reality, the secret agent enjoys no such luxury” (Le Carré, The Spy Who Came in From the Cold 9). In fact, for the spy, their creations, their illusions can become realistic entanglements if they allow them to do so. For Alec Leamas, the main character in the novel, maintaining his persona, even when alone and not in a mission is sensible and damaging. Normally, spies create cover stories that are deliberately close to their life reality in order to defend themselves and maintain plausible deniability, but by being a spy first, then an individual, Leamas intentionally blinds himself to the moral and ethical inconsistencies of the profession (Beene 51). This lack of individual separation allows for multiple conflicts to arise within the text. Most importantly, since Leamas becomes a physical representation, a signifier per se, of the British intelligence service, he is placed in direct opposition of Hans-Dieter Mundt as the embodiment of the Communist Party, thus setting up the opposition of the Circus versus the Party, as it is referred to, through Leamas and Mundt. Therefore, the main opposition in the novel is centered on what Derrida considers one of the most important pairs of opposition which govern the basis of Western thought: good versus evil. This binary opposition, as those of metaphysical concepts (speech/writing, presence/absence, etc.), "is never the face-to-face of two terms, but a hierarchy and an order of subordination” (Derrida, Margins of Philosophy 195). Furthermore, according to Derrida, this binary opposition "must therefore be neutralized" in order for meaning to be extracted (Derrida, Of Grammatology 188-189). In "The Spy 
Who Came in From the Cold” the Circus represents the perceptions of a free world through democracy while the Party symbolizes the oppression of the people through the belief of communism as a solution for collective equality.

At the beginning of the novel, the reader is introduced to the main character, Alec Leamas, who has been in the intelligence service for an undisclosed amount of time, but one can assume it has been a lengthy career. Shortly after, Liz is introduced as a young Communist whose loyalty to the Party is idealistic and romantic, with little understanding of the socio-political effects Communism has in the world. Leamas embodies the current state of the Circus as an institution eager to revalidate itself in the presence of two emerging superpowers, the United States and Russia. Consequently, Leamas is the favored element by Le Carré in the binary opposition as he is representative of the Circus and democracy. However, as Leamas approaches the end of his service, he finds his reputation tarnished by the death of agents he was in charge of as well as the popular and political rise of his nemesis, Hans-Dieter Mundt, a high ranking leader of the Communist Party in East Germany. From the beginning, the reader understands that for Leamas, life as a spy has been anything but glamorous. It has been a career filled with frustration, anger and resentment toward the political system, intelligence service, and society. And when the retirement is near, the forthcoming isolation would be disastrous, at times comparable to living the rest of his life with “cancer or imprisonment” (Le Carré, The Spy Who Came in From the Cold 130). Now, these are two interesting words in the text because they define life-long ordeals, but do not provide a clear option or closure to a spy’s life after concluding service. Le Carré goes on and gives the impression that upon 
retirement, a spy lives the rest of his days in "cynical resentment [while gathering] the courage to face a solitary existence" (Le Carré, The Spy Who Came in From the Cold 9). By presenting this debilitating state of mind for the spy, the reader begins to wonder about the events and the experiences during the years in service that could have turned a man into an acrimonious person. The answers come rather quickly.

Leamas, from the beginning of the novel, reveals himself to be a character full of hopelessness and contempt towards society and those he serves. Much of his pain and suffering during his service, and presumably after he enters retirement, come as a direct result of his years dedicated to the Circus. One plausible cause for Leamas, as for those in the intelligence community, may be that "intelligence work has one moral law - it is justified by its results" (Le Carré, The Spy Who Came in From the Cold 10). "Results" is chosen by the author to indicate a final conclusion, not a process of gathering information or the relationships a spy must have with his handlers, but the closure of events: the fall of Communism, the rise of the Circus, the decline of British intelligence over the growing presence of the American Central Intelligence Agency (CIA), etc. Such events clearly make the spy a tangible asset that can easily be replaced given the conditions or political climate. Therefore, Leamas, as a spy feels vulnerable and used by an agency that does not value the individual, but instead focuses on maintaining an ideology intact.

Evidently, it can be argued that Le Carré favors Leamas for representing the binary element of the West, for the sacrifices he has made, and for his ignoble treatment, which is exactly what makes him noble to the reader; he endures, carries out his mission, even though he will receive no laudatory praise, but completes his mission as an 
intelligence officer regardless of the cost. Consequently, "The Spy Who Came in From the Cold" depicts two elements that lead to Leamas being heroic, but falling short of completing his goals. First, the spy is never in control. He only follows orders based on the vision of the few in command. Second, for the spy, the job and his duties are a series of "coincidences and alternative solutions to gain operational convenience. This allows the spy to master his craft of deception, but leads him to an unfilled personal existence. On this premise, Le Carré chooses to create Leamas as a character void of emotional sentimentalism, but with professional devotion to follow institutional goals in order to separate his protagonist and the text from the mainstream expectations of morality and justice in espionage. Through Leamas, Le Carré reveals the frustrations of the spy and the misconceptions of society: "What do you think spies are: priests, saints, and martyrs? They're a squalid procession of vain fools, traitors too, yes; pansies, sadists, and drunkards, people who play cowboys and Indians to brighten their rotten lives” (Le Carré, The Spy Who Came in From the Cold 217). As an individual, Leamas finds comfort and a sense of purpose only in his work and the environment in which operates. The failure of his German network, Riemeck's death, along with the dissatisfaction in his personal life, made the "cynical, bitter, and tiring” world of espionage a fitting place to offer him redemption because it's the only world he knows (Le Carré, The Spy Who Came in From the Cold 15). Control's last mission also becomes his last opportunity to regain his humanity before incorporating himself into the ordinary world.

The conflict of good versus evil, as represented by Leamas and Mundt, is an interesting struggle to focus on since it reveals more about Leamas and the way the Circus and the Party operate. Mundt is a man that is absent for much of the novel in terms 
of physical presence and influence, yet his status as "the enemy" is what shapes Leamas' destiny and encourages his professional devotion. But Mundt, as an idea, hinders Leamas' humanist sentimentalism. To a certain extent, it can be argued that Mundt, through his physical absence and indirect conflict with Leamas, is able to define the Circus and the way it operates, which can be concluded to be mainly on false perceptions and attitudes. By creating Mundt as an iniquitous presence for much of the novel, and seeing the professional, personal, and social struggles Leamas goes through in order to find and eliminate him, Leamas rises to a level of heroism within the novel that no other character is able to achieve. In a way, by not confronting Mundt in person, Leamas is trying to pursue and vanquish not just a man, but an idea represented by a powerful and ruthless criminal bent on seeing Communism rise and spread across individual states. The novel then presents Leamas' decision for isolationism as a form of sacrifice in order to focus on completing his mission which is to capture the traitor and bring him to justice.

However, when the text finally introduces Mundt and describes his role in the Party, it becomes difficult to justify the actions by the Circus or dismiss Leamas’ drunkenness and permanent anger. If the Circus, or the privileged notion of 'Good' is placed under erasure, or sous rapture, the novel gives the reader a different perspective of the Party. ${ }^{13}$ Under erasure, what "The Spy Who Came in From the Cold" reveals is that the Gireus, from the perspective of Party, has been a collection of ideological and philosophical misconstructions in order to justify its inadequacies and flaws. The Circus has stood for order and peace, or at least for the protection of British interests in Europe.

\footnotetext{
${ }^{13}$ Sous rature, or "under erasure," is to write a word, cross it out, then print both word and deletion. "That mark of deletion is not, however, a negative symbol. Under its stroke the presence of a transcendental signified is effaced while still remaining legible” (Derrida, Of Grammatology 23).
} 
After World War II and through the Cold War, it stands for democracy and progression of its ideals as a way of countering the threat of Communism. In the eyes of the world, or as projected by the Circus, it has also operated by following a defined set of parameters and guidelines all centered around "intelligence's one moral law - the justification by results" and the need to contain Communist ideology from spreading into other countries beyond Russia and those already aligned with its anti-Western philosophy (Le Carré, The Spy Who Came in From the Cold 10).

But the Gireus has a lot of accumulated meaning that needs to be denounced before completely accepting it as an entity of 'good' during this tense historical time period. The meaning behind the Circus involves all the defining characteristics of British intelligence that have weakened, or failed as Soviet Russia and the United States have risen to power. At some point, the Circus represented order or at least the prevention of chaos in the region while Great Britain was still an empire. After World War I, the Circus was seen by the rest of the world as an agency dedicated to innovation in the practice of espionage, as the British Intelligence Agency was the premier intelligence gathering body before the KGB and the CIA. However, under erasure, the Circus loses all the elements that historically have defined it, including its purpose. And unlike the Circus, the Party knows what its defining mission is and the purpose it serves for the people. By the end of the novel, however, the reader is able to understand that Circus and Party are interchangeable concepts and entities whose purposes do not differ greatly. "All our work - yours and mine - is rooted in the theory that the whole is more important than the individual. That is why a Communist sees his secret service as the extension of his arm, 
and that is why [British intelligence] is shrouded in purduer anglaise"'14 (Le Carré, The Spy Who Came in From the Cold 114).

Once Leamas and Mundt meet, it is evident that both organizations are not concerned with the individual, nor are they concerned with the preservation of an absolute ideology. Linguistically, the word ideology is one that needs to be closely examined in order to understand that Leamas and Mundt are both victims of their beliefs. Ideology "refers to a belief system and specific beliefs that induce false consciousness" (International Bulleting of Political Psychology). In the novel, ideology is the aporia, or the contradiction that creates the mirage of righteousness for the Circus or the Party. Neither entity is adopting and implementing the 'right' action in terms of implanting an ideology. In fact, the Circus and the Party, as well as the individual spies, Leamas and Mundt, have "beliefs about the world and one's place in it that perpetuate the degree to which one is exploited by others with more political power. In essence, one is unwittingly complicit in the other's exploitation by maintaining such beliefs” (Schwartz 46). The concept of ideology then signifies that for Leamas, his belief in the intelligence and the crafted lies by the Circus will undoubtedly lead him to isolation and eventually his death, which ultimately occurs. And for Mundt, the continuous following of the Party's ideology will allow him to progress professionally and personally up to a certain point, before he becomes a victim of his beliefs and either rejects the defining principles of the Party or completely submerges himself in them and loses all traces of identity, leading him to suffer a fate similar to Leamas.

\footnotetext{
${ }^{14}$ A term used sarcastically to refer to British mannerism and maintenance of proper etiquette and composure even in the face of emergency or calamity. In this particular case, it refers to the irrelevance of England as a political power during the Cold War.
} 
Although the operational methods of espionage and intelligence gathering of the Circus and the Party are different, both organizations seek results that will help fulfill their mission. It is within their approach, their methodology of foregoing the needs of the individual and means justifying an end that their institutional principles intersect. The Circus needs the Party in order to justify its existence and to be able to identify its flaws. In fact, it can be argued that the Party provides the Circus a sense of guidance and ultimately a philosophy. Similarly, the Party needs the Circus in order to validate its actions. If the Party is to pursue a globally-accepted socio-political philosophy, then the Circus would not be concerned with containing or trying to prevent it from spreading its message and its ideology of governance may very well be accepted in the international stage. But because the Party is pursuing a hard-line definition of Communism, the Circus monitors it, and the interest on the Party by the Circus becomes an affirmation or a source of philosophy for the Circus.

Besides ideology, "philosophy" is another word that reveals opposition and disunity in the novel. Fiedler, an Eastern intelligence officer debriefing Leamas and gathering evidence in efforts to make a case against Mundt as a traitor, candidly asks Leamas, “What makes [spies] do it? They must have a philosophy?” (Le Carré, The Spy Who Came in From the Cold 124). Philosophy in this sense is a laden word containing the humanity of the spy. At first, the implications of the philosophy of a spy can refer simply to the collective belief of the agency as executed by the individual spy. Perhaps the answer is simple: to protect British interests and uphold the principles of democracy in the face of a growing Communist threat. That answer would seem to satisfy the 
inquisitiveness of Fiedler. However, Fiedler offers the philosophy of the Party as a counter-example to demonstrate that British intelligence has no guidance, no direction, and no principles for what the spies are really fighting for, much less a philosophy they are trying to uphold. This revelation puts in question everything that Leamas has known and worked for throughout his life. Fiedler, in continuing to inquire about the "philosophy” of the Circus, attempts to tie the word to another, "justification.” He states that the Party's philosophy and justification for being is to be "the vanguard of the fight for Peace and Progress” (Le Carré, The Spy Who Came in From the Cold 124). In contrast to Leamas, Fiedler reveals this truth with great determination, sincerity, and a tone of optimism that is impossible for Leamas to match. To the reader, at this point, Leamas' purpose as a spy, as a human being, is superfluous and futile. This textual inversion changes the reader's perception of the work and existential necessity of Leamas, the Circus, and of espionage in general. What is the purpose of secrets if they have no value in terms of performing a function for society? After a brief conversation regarding institutional philosophy and its meaning as applicable to the Party and the Circus, it is clear that the question about philosophy and purpose carries greater implication, and demands questioning the values, ethics, reason, logic, and morality. Now, the reader understands why Leamas is a frustrated individual. Leamas himself now understands, thanks to Fiedler, that all spy "work is rooted in the theory that whole is more important than the individual” (Le Carré, The Spy Who Came in From the Cold 114).

The implications of Leamas and the Circus not having a "philosophy" are profound. For Leamas, lacking a philosophy by which to live as a spy reveals an absence 
of character and purpose. It means that his entire life, his career, and his sacrifices have been in vain. Institutionally, not having a philosophy weakens the Circus since a philosophy and all its implications of order and ideological pursuits are structures of power. Power, however, cannot be exercised unless there is an economy of discourse - or an understanding of how power is produced, accumulated, and circulated (Foucault 24). Therefore, philosophy establishes a purpose as a source of power that must be handled according to core principles, values and mission. Power is also important for the Circus and is what Foucault considers it to be a self-leveling element that allows any entity to find itself and its true purpose (Focault 27). From a humanist level, the absence of a philosophy of duty, or enterprise, also eliminates a significant number of defining characteristics of representation that are tied to the complex guidance of human rationale. This indicates that Leamas does not possess, as an extension of philosophy, rational thought, reason, ethics and morals, thus lacking the most basic beliefs and attitudes for an individual to function properly in society. Leamas is then left to search for these qualities in people and places he soon rejects, or which may lead him to further isolation.

Being at the core of the novel, philosophy becomes another term of différence. Derrida's term, which is neither a concept nor a word, is defined as a "systematic play of differences, of the traces of differences, of the spacing by means of which elements are related to each other, thus allowing moments of meaning, and transformation of a word" (Derrida, Positions 27). From a Derridian approach, the philosophy of both the Party and the Circus refers to the purpose for which each entity exists. However, purpose itself can only exist if the Party and the Circus do not have meaning for what they intend to do as institutions. But meaning is a problematic term for both entities since the political 
conditions during the Cold War kept the political landscape in Europe constantly changing. In addition, meaning also changes considerably due to the internal fluctuating nature of both organizations. During the Cold War the Circus, as an institution, was dealing with its own crises of low morale in its employees, finding its purpose amidst Russian and American intelligence agencies position of dominance, and rising geopolitical power by the United State. Alternatively, the Party itself was dealing with problems of identity and unity as it spread its influence to the West. Ultimately, in "The Spy Who Came in From the Cold," the Circus and the Party operate in the trace of their philosophy since a true philosophy can neither be obtained, and their sense of their own purpose will always be evolving. The trace, as Derrida points out, is the spacing by which philosophy relates to purpose and finally to meaning where "one always inhabits, and all the more when one does not suspect it” (Derrida, Of Grammatology 24). This constant linguistic change in approach to their actions leaves the Circus and the Party constantly aiming for an unknown future. They are always trying to reach a goal, a purpose that in the present is always undefined. Therefore, although the question of philosophy comes up between the Circus and the Party, neither organization has one and can only aim to define their presence during the present conditions of the 1960s.

Through the predominant conflict between Leamas and Mundt at the individual and representational level of the Circus and the Party, respectively, the novel structurally holds up as a fluctuating tension between good versus evil. It is the archetypal conflict of who is right and who is wrong based on universally accepted morality. Although the reader is able to understand each angle and point of view of the novel based on the role of each individual and organization, the text is undermined by the presence Liz as the 
representation of true ideology. In the text, Liz is the innocent embodiment of the blind society that was looking for peace and a better world after World War II. She is young, caring and beautiful - qualities that no longer exist in the world of Leamas or Mundt, or the Party and the Circus. The text introduces her as a support system for Leamas, helping him through illness, his own bitterness, and his journey to find purpose in life.

Throughout the novel, Leamas is a man who “doesn't like Americans or public schools, military parades or people who play soldiers, much less conversations about Life” (Le Carré, The Spy Who Came in From the Cold 31). Ultimately, she falls in love with him, a man thirty years her senior, but it can be argued that she is in love for who he was and for the idealism that once motivated him, and not for the man "who has sworn vengeance on something” (Le Carré, The Spy Who Came in From the Cold 32).

Although the text dedicates only one chapter to Liz, it functions as a transitional episode between Leamas' pre-retirement failures and his last attempt at redeeming his career at the Circus. With Liz, Le Carré could have created a more robust character through which the reader would have seen that there is hope in the world of espionage, and demonstrate that there is hope for a better life, even for a failed spy; but unlike Liz, Leamas "is not accustomed to living on dreams" (Le Carré, The Spy Who Came in From the Cold 41). Although Liz is twenty-four-years old and an avid member of the Party, she is defined by her subtle innocence, candor for life, and personal philosophy. Liz's presence then becomes a contrast to Leamas' own mystery and misery. In the text, Liz is a missed opportunity to present to the reader a more complete portrayal of Leamas as the individual, as the person outside the confines of the Circus. Instead, the text only reveals 
Liz through generalized characterization, leaving her as a flat character with great potential to add depth to Leamas and Mundt. Liz could have been the unifying element, the empty space between the dichotomy of good and evil as she is able to tread both worlds. Through a projection of her idealism toward the Party and her nurturing of Leamas as a lover, Liz would have defined both sides of the dominant dichotomy so that the novel itself would be able to support and develop a better sense of morality and address the question of why does a Western spy, or a communist, follow the path he does.

Liz, by all accounts, lives a sheltered life. As a young member of the Party, she is impressed by the social and political powers that are continuously shaping the world around her. Perhaps it is safer for Le Carré to make her a plot device and under-develop her character rather than have her be one who can possibly undermine Leamas's role in the novel. Le Carré chooses to make Liz an observer and an innocent bystander committed to her job as a library clerk and making mundane contributions to the efforts of the Party in London. If she would have been more involved in Leamas' affairs, the Circus, or in her own development as a member of the Party, her character would have created a grave internal conflict within the novel that may have left it open to any interpretation. Although she is dedicated to Leamas's well-being while insisting on developing an emotional connection with him despite suspecting he is a spy, Leamas sees her as blind and ignorant to the dangers of the world. He sees her as a young, naive youth curious about the ideological factions of the world and within herself. This is evidenced when after "becoming lovers," she is "blushing like a small girl...and feels so proud.” In contrast, he is "quiet and ashamed” but holds no regrets (Le Carré, The Spy Who Came in 
From the Cold 32). In Leamas, Liz only sees a man of passion and devotion, whose lifelong dedication has been to espionage. As part of his final mission, Leamas leaves London and Liz behind. However, what would have occurred if Leamas had stayed in London with Liz? One simple answer would be that the novel falls apart because the spy is no longer doing his duty, and Liz, is an impediment to the conflict of the story. Therefore, it was important for Le Carré to discontinue their relationship since a possible union, perhaps not marriage, ultimately, but a relationship at the very least would have demonstrated that conflicting ideologies are able to coexist. Whatever their individual goals, Liz would not have abandoned the Party, and Leamas would not have walked away from the Circus. However, this communion of philosophies had to be prevented in order for the blurred line between good and evil not to become invisible.

Aside from structural tangents like Liz, there are other elements in the novel that affect its meaning. The reference to the cold, for example, has a spectrum of interpretations. From the title of the novel to Leamas's operational environment, the cold is a state of being for the individual spy in which all emotions are foregone. In the cold, identity is no longer defined by individualism, but by the needs of the collective purpose, or mission. The 'cold' in the novel is a particular layer of existence between social reality and functionality that completely changes the persona. For spies, the cold is where they operate. It is a comfort zone of secrets, treachery and deceit where they navigate with expertise and familiarity. The idea of a safe-zone in the dark bosoms of society allows the spy to find meaning to their existence as a professional and sometimes as an individual. For Leamas, the cold has become a lonely place inhabited by agents who are no longer 
functional and have been discarded by the agencies that used them. Rejecting this cold environment in which he has operated for many years is not a choice. Close to retirement, the cold is the "price he paid, an environment where he [learned] to hate God and Marx" (Le Carré, The Spy Who Came in From the Cold 218). In terms of ideas, the cold represents a lack of ideals which have served as catalysts to the Cold War. But this fabricated reality, or safe-zone, voids the individual of sentimentalism, identity and relationships which must be replaced. In the case of Leamas, as with other characters created by Le Carré, alcohol helps fill the void by bridging the world of the spy and that of regular citizens. ${ }^{15}$ In the novel, the cold transcends from a frame of functional reference to a state of mind and ultimately to a state of being. Spies that adapt to the cold as an existential environment find it impossible to escape and re-integrate themselves to the greater population once they leave the intelligence service. For spies, the cold is who they have become.

Like the concept of the cold as an ambiguous term for operational and emotional emptiness, "The Spy Who Came in From the Cold” also presents the Berlin "Wall” as term that helps the reader trace Leamas’s plight. Spies, like regular people, "are not just producers of language, but are themselves constructed by the linguistic structures in which they function from within” (Wolfreys and Baker 76). For much of the novel, reference to the "Wall," captures and to a certain extent helps define the Cold War. Throughout much of the novel, there is a constant, ominous reference to this 'sign' as an entity that adds depth to the story of every character. Just like the institutional and

\footnotetext{
${ }^{15}$ In his novels, Le Carré incorporates alcohol as a preferred coping mechanism for spies. While in the intelligence service, he drank heavily in order to deal with the "pain and insanity of a world war and soften his troubled conscience, thus, making distasteful service more permissible” (Beene 31).
} 
individual 'philosophy,' the 'wall' is a term of différence. Historically, the Anti-Fascist Protection Rampart, or the Berlin Wall as it was commonly referred to, was a physically imposing presence that separated the German Democratic Republic and the German Eastern Bloc. But the novel does not provide a physical description of the wall, only the subjective implication of a wall, or what Derrida would consider a sign of multiple metaphysical properties that is "essentially theological. Perhaps it will never end. Its historical closure is, however, outlined" (Derrida, Of Grammatology 14). On a basic representational level, the wall is the clear physical and psychological structure that divides Germany. But in dividing a country, it also becomes a separator of alliance toward Western democracy and Eastern communism. Subsequently, the wall becomes a construct that transcends physicality and becomes a defining edge between Communist political idealism and democracy; Leamas symbolizes the pursuits of the latter, and Mundt becomes the embodiment of Communism as a new world order. However, in the novel, "the Wall was the perfect theater and the perfect symbol of the monstrosity of ideology gone mad" (Le Carré, The Spy Who Came in From the Cold x). In fact, "the Wall was a catalyst that turned the espionage industry more clandestine, more perilous, more questionable" (Le Carré, The Spy Who Came in From the Cold xi). For the individual characters, in particular Leamas and Liz, this separator of ideologies becomes an emotional blockade preventing them from being together as Liz would have wanted, or as Leamas would have needed in order to recover a sense of humanity. Ultimately, “Liz's main role in the novel is to develop and modify the monolithic rock of Leamas's pedestrian psychology" (Cobbs 50). In the end, for Leamas and Liz, the wall is the difference between life and death as they attempt to cross over into the safety of Western 
Germany. "Shielding his eyes he looked down at the foot of the wall and at last managed to see her, lying still. For a moment he hesitated, then quite slowly he climbed back down the same rungs until he was standing beside her; she was dead” (Le Carré, The Spy Who Came in From the Cold 224). It is almost impossible to decide what happens at the end of the novel when both lovers lay dead on the communist side of the wall. Perhaps it was an accident and Liz slipped and could not hang on, or maybe it was a result of poor timing and lack of communication between Control, or Mundt with Leamas. Regardless, their death serves as a reminder that in espionage, the disregard for human life and decency is what characterizes the profession.

The story of the spy is a story of loneliness. Le Carré sets the story of Alec Leamas during the Cold War, allowing the historical period to give the novel the necessary depth and atmosphere necessary to portray his disenchantment with espionage. In the novel, the main character is depicted as someone who is in a state of limbo and undergoing a mea culpa for failing himself as an individual and failing those he serves. At a deeper level, the novel is about the conflicts of the individual. In Leamas, the reader finds immutable failures which he must spend a lifetime trying to correct. In the case of "The Spy Who Came in From the Cold" Leamas must rediscover his own true self, or die in the process. 


\section{MEANS JUSTIFY MY END}

In “Tinker, Tailor, Soldier, Spy” (1974), John le Carré continues the development of his most notable character, Gorge Smiley. ${ }^{16}$ As in his two previous novels, "Call for the Dead” (1961) and a "Murder of Quality” (1962), Le Carré again portrays Smiley as a distinguished British intelligence agent and an enigmatic figure who embodies the decadence of espionage, while nostalgically displaying the moral foundations of the profession as it was intended to be. For Le Carré, Smiley is a profound symbol of what "could have been" and what "should be" in regards to the work performed by Secret Intelligence Service agents. The character he creates gathers the essential components of the spy trade, enhancing them with the personality of a true gentleman "who epitomizes British decency and the ineffectual efforts of an existential humanist beset by the psychological and moral dilemmas” (Beene 24). But with all the diligence and attention devoted to his character and his expertise in intelligence matters, in George Smiley, Le Carré also conceives the imperfect spy.

Much like “The Spy Who Came in From the Cold” (1963), “Tinker, Tailor, Soldier, Spy” (1974) opens with a blown operation in Czechoslovakia and the shooting and capturing of a British intelligence officer, Jim Prideaux. This incident forces Control and his deputy, George Smiley, into retirement. Control, already ill, dies soon after. Through a love affair with the wife of a Russian intelligence officer, British agent Ricki

\footnotetext{
16 "Le Carré claims George Smiley is a composite of James Skardon, the man who interrogated Klaus Fuchs, the nuclear physicist who sold American atom bomb secrets to the Soviets, and Vivian Green, the history don who taught David Conwell, Le Carré's real name, at Oxford and married him to Ann Sharp.” He first appeared in the novel Call for the Dead (Beene 148).
} 
Tarr discovers there may be an infiltrated high-ranking Russian spy in the Circus. Tarr notifies Peter Guillam, his supervisor, who in turn notifies Undersecretary Oliver Lancon. Lancon, who oversees intelligence services for the British government, enlists George Smiley to investigate and seek out the mole without the Circus finding out. In charge of the Circus is Sir Percy Alleline and his deputies, Bill Haydon, Toby Esterhase, and Roy Bland - all of whom are possible Russian mole. Alleline turns out, rose to the head of the Circus as a result of top-top grade Soviet intelligence from a source code-named “Merlin.” Smiley’s investigation leads him to believe that Merlin’s information is false and is being used by Moscow to manipulate the Circus. In the meantime, Smiley is dealing with memories of Ann, his estranged wife with whom he has an on-and-off marriage and weighs him heavily, emotionally, as it haunts him throughout the novel. Once Smiley has enough information about the Soviets' infiltration and manipulation of Circus agents, he confronts Alleline and his deputies about his findings and consequently reveals Bill Haydon as the Russian mole. As a result, Alleline is removed from his position and Smiley is appointed temporary head of the Circus.

“Tinker, Tailor, Soldier, Spy” is constructed as a series of flashbacks pieced together in order to solve the riddle of the Soviet mole in the Circus. Each flashback is a segment of a puzzle focusing on an individual, his actions, and his morality. This intelligence puzzle reveals multiple conflicts that threaten the very nature and existence of British intelligence. At its core, the novel's narrative conflict is set up by the infiltration of a Soviet spy, a mole, into the upper ranks of the Circus. The novel also emphasizes Smiley's pursuit of an eventual union with Karla, the fictional Soviet 
spymaster during the Cold War. This traditional spy dilemma allows the text to explore each character individually and examine their role within the intelligence agency. Every character in the novel has an interesting story to tell, usually of internal conflicts derived from the work they perform, or emotional disillusionment all related as part of Smiley's investigation into uncovering the mole

But George Smiley is by far the most conflicted agent. His character sets up the internal tension of the novel by representing a set of oppositions that align the structural narrative directly with his ability to deal with his personal and professional conflicts. In Smiley, Le Carré places the internal and external conflicts that set up all ambiguities concerning the Circus and the individualism of Smiley as a spy. In Le Carré's divided world, "one truth is that the elaborate intelligence machinery doesn't matter very much, [instead] he points out repeatedly, that although institutions may kill for power or pride, people pay in suffering and death” (Cobbs 22). But beyond the espionage and intelligence puzzle, “Tinker, Tailor, Soldier, Spy” is also a quest in which George Smiley sets out to reconcile disillusionment and unfulfilled realities more than the need to root out a mole. Smiley's role in the Circus is symbolic to that of a troubled knight who sets out in search for the "Black Grail,” for Ann, and to restore glory of England. ${ }^{17}$

For the purpose of this chapter, I have set up the binary opposition in "Tinker, Tailor, Soldier, Spy” as a situation in which there are two opposing versions of George Smiley. The single character pursues two individual goals: one for himself, and one for

\footnotetext{
${ }^{17}$ The Black Grail in its most direct meaning is a reference to Karla, the Soviet spymaster. However, the Black Grail is interchangeably used in reference to the "means to whatever end" approach George Smiley takes in his pursuit of Karla (Beene 89).
} 
the Circus. This branched duality sets up the complex dichotomy in the novel in which the first, or what can more accurately be described as the "old," Smiley is the embodiment of the establishment and the one spy who is placed in charge of protecting the historical integrity of the Circus from outside influences. The other version, or the "new" George Smiley, is the one who accepts the task of "cleaning the stables, to go back and forth and do whatever is necessary to protect his legacy,” and eventually is the one character left in charge of the Circus once the mole is uncovered (Le Carré, Tinker, Tailor, Soldier, Spy 78). Both sides of Smiley are characterized by nostalgia for hegemony, and a resolute sense of duty that places him between ideology and reality. Yet, each version of Smiley sets out to accomplish different personal and professional objectives.

The novel introduces George Smiley as a retired spy recalled into service after learning that the Circus has forgotten the lessons of an untold past. The revelation of a Soviet cipher-clerk threatens the institutional functionality of the agency as well as the lives of various agents. This recall into service allows the most significant conflict in the story to develop. For the "old" Smiley, the reintroduction into the service triggers a set of personal and professional dilemma: 1) in order to root out the mole from the Circus, he must face the harsh lessons from the past and directly confront the spies from "his generation” to preserve the integrity of British intelligence, and 2) professionally, he has to accept and overcome the "sheer vanity of believing that one fat middle-aged spy is the only person capable of holding the world together” (Le Carré, Tinker, Tailor, Soldier, Spy 79). Smiley, throughout his career, has been a student of British intelligence. This means 
that he not only remains apt and skilled in his craft, but that he is well aware of the historical foundations and teachings that make up British intelligence up to the period of the Cold War. He is aware of the challenges spies face, but more importantly, he is prepared for the damaging consequences of espionage on the individual. The "old” version of George Smiley retrospectively looks at the past and follows the principles and teachings of Control, the now absent former head of the Circus. For the text, this is a problematic disposition since it opens Smiley to the opportunity to commit the mistakes which have led the agency to its present state. By returning to the Circus, George Smiley finds himself torn between the past and the future. This conflict places Smiley as the spy in charge of discovering the mole while allowing him the opportunity to become a representation of the Circus during the Cold War and the model for future spies and leaders.

In reading the novel as a postructuralist construct, the "old,” more conservative version of Smiley is the favored element in the dichotomy. He symbolizes what the Circus and intelligence work should be: simple, but efficient. As a man, George Smiley is best captured in the words on Lady Ann Sercome: he is a man who is "breathtakingly ordinary and consumed by duty” (Le Carré, Tinker, Tailor, Soldier, Spy 79). For the reader, the simplicity of her statement, juxtaposing two seemingly opposite character traits, exposes the complexity of his character. But Ann's encompassing evaluation of her husband allows the reader to understand that George Smiley is a paradoxical creation even in his wife's opinion. Le Carré goes on to describe Smiley as “short, fat and of quiet disposition... one of London’s meek who do not inherit the earth” (Le Carré, Tinker, 
Tailor, Soldier, Spy 18). In contrast, after such an unflattering description of Smiley, Ann is juxtaposed as aristocratic, social, beautiful, and young. This contrast of the ordinary man marrying someone who is the complete opposite serves to foreshadow the struggles he will face in discovering the mole while confronting a stale past and the need to reinvent himself.

In contrast to the "old," romantic perception of George Smiley, the "new" version, which represents the second half of the dichotomy in "Tinker, Tailor, Soldier, Spy," is the re-imagined representation of an old spy who has spent his career in the cold. The "old" version ended with retirement, ironically forced upon him after believing there was a Soviet mole within the ranks of the Circus. As the symbolic knight, the "new" Smiley returns to find a kingdom enmeshed in intrigue and disarray as a result of individual interests eclipsing institutional goals and ideals. Smiley finds the Circus in a debilitated state where operatives are hopeless, and the permanence and credibility of the institution is quickly eroding in the international arena. George Smiley is then summoned as the heroic figured who will "rebuild Camelot” (Le Carré, Tinker, Tailor, Soldier, Spy 108). However, the allusion to the legendary kingdom is problematic for the reader and the text. For the reader, Camelot connotes the heroic implications of an unshakeable kingdom of prosperity and peace, where King Arthur and his knights relished in the spirit of adventures and quests, where chivalry flourished and bravery was rewarded. However, in spite of the potentially triumphant intentions of a noble knight, for the text, the allusion to the legendary kingdom foreshadows a grim future for the Circus as Camelot, and for Smiley as the betrayed king. Camelot also brings forth recollections of internal struggles, 
deceit, and treason, all contributing to the implosion and eventual collapse of the kingdom. By depicting Smiley in relation to the historical king, the text transfers the leadership traits and the flaws of the legendary monarch to the spy. Therefore, Smiley should acknowledge that rebuilding a kingdom can have devastating consequences on the individual, especially if this new Camelot is destined to have the fate of the legendary one. The text, however, still places Smiley as the one spy capable of achieving the impossible in order to take a kingdom and elevate it to glory.

As the quest to rebuild Camelot begins, the "old" Smiley embarks in his journey as the archetypal quest hero. As it often happens in heroic quests, Smiley sets out against his will, on a journey across treacherous borders to reach evil, defeat it, and reestablish the status quo. ${ }^{18}$ The hero, normally a man of extraordinary abilities, must distance himself from the people he intends to protect in order to be effective in his mission. However, this separation, for the hero, can be potentially dangerous. As a spy, Smiley faces temptation, the cold, the alienating nature of espionage, and even death. He must rely on his judgment and personal philosophy in order to avoid being trapped between institutional politics and personal beliefs. Smiley, as the hero, understands he will have to sacrifice some elements of himself in order to accomplish his mission.

As Smiley sets out on his quest, he is driven by the vision of the past, when espionage was a glorified art-form, centered on storied agencies and long philosophical conflicts that often took entire careers to resolve. But through Smiley, Le Carré is able to

\footnotetext{
${ }^{18}$ The status quo can refer to a balance between opposite forces. In a conflict, the positive, or at least the most beneficial character or nation to humanity, prevails and the negative forces which are often associated with chaos, disorder, and evil are subdued or defeated. In the case of George Smiley, the implicit status quo is the reestablishment of England as the dominant empire post World War II. This position would perhaps eliminate all the global conflicts and eradicate Communism.
} 
accept, albeit begrudgingly, that the glory days of England's almost-mythical spy agency are in the past, and after the Cold War, the future belongs to America. Nevertheless, Smiley takes the form of a modern-day King Arthur, one who is undeterred, marching steady toward a battle, knowing that he may be defeated but not vanquished. Therefore, like King Arthur, the text elevates Smiley to an authority figure in English intelligence, waiting for the right moment and opportunity to come back to England and begin a new golden age of espionage, and restore glory to the British intelligence service.

But like King Arthur, Smiley is eternally cuckolded by the female presence. To a great extent, Smiley suffers from his failed marriage to Ann and for the "hypocrisies and the occasional brutalities of Western intelligence procedures” his country has adopted (Cobbs 25). England at this time was a nation that suffered during the Cold War as it transitioned from an empire to a nation state, and found itself helpless due to its eroded position in global politics. After World War II, England had become irrelevant and was in the middle of a historical conflict between two emerging superpowers, the United States and Soviet Russia. In “Tinker, Tailor, Soldier, Spy,” Le Carré infuses his sentiment of impotence and frustration that escalates to anger and resentment toward the changing political field, “especially toward those damn Yanks," culminating in a sense of hopelessness for Smiley (Le Carré, Tinker, Tailor, Soldier, Spy 152). England is a country that, according to popular accounts in its history, has been destined to rule. But, during the Cold War, nationalist Britons including George Smiley "have watched all the expectations born from imperial privileges disappear. [England was] trained to Empire, 
trained to rule the waves. All gone, all taken away" (Fisher 37). Smiley, like the rest of England, can only watch the world transform from the sidelines of history.

For Smiley, as for England, the role of being an insignificant middle-man in the intelligence exchanges shaping the world during the Cold War, points to a resignation and acknowledgement that as an empire, as an exemplar of intelligence, the country and the Circus must accept a continuous decline in its global role. This dissolution of power permeates throughout the novel, and at times, Smiley's quest becomes more about regaining prominence for England than capturing Karla or the mole. In the Circus, England's declining position in relation to the United States has led to "low morale, internal feuding, and the red tape that ties an agent's hands even while being deceived by [their] superiors. These internal struggles have killed the spies' belief that their work in intelligence can influence the clash between good and evil" (Beene 90). With personal, institutional, and now national identity struggles compounding, the odds are against Smiley and his efforts to rebuild Camelot. Towards the end of the novel, in a meeting with Karla, upon revealing his disposition and ideology, Smiley is referred to by Karla as a "fool, one who entertains those in power," in this case referring to Control (Le Carré, Tinker, Tailor, Soldier, Spy 303). For the reader, the paradox in which Smiley exists comes to mind. Perhaps Karla is right in labeling him a fool. He does not perceive Smiley as a King Arthur figure, nor as a person capable of saving a failing kingdom with what is implied to be an archaic ideology.

In a personal sense, the "old” Smiley is also cuckolded by his wife, Ann. Their marriage symbolizes his steadfast loyalty despite repeated betrayal. Although the reader 
does not “meet” Ann in “Tinker, Tailor, Soldier, Spy,” her presence in Smiley’s life is still significant. In the text, she appears in Smiley's memory throughout the flashbacks that structure the novel. She is presented only as a point of reference to Smiley's past, one riddled with guilt and the possibility of a future with his wife. However, Smiley's memories of their conversations still command a part of his life. In his recollections, as in their marriage, Smiley blames his loneliness on his work. However, Smiley also remembers that at one point, Ann had suggests that in order to save himself and their marriage he should "burn the lot, set fire to the house. But don’t rot” (Le Carré, Tinker, Tailor, Soldier, Spy 79). By rotting she means conforming to the demands of the work and sacrificing himself, though no one, least of all Ann, thanked him for his effort. Before setting out to find the mole, "After retirement, Smiley had dedicated himself a full time profession of forgetting his past. He had dedicated himself to scholarly pursuits which had served him as a distraction while at the Circus, but which now that he was retired meant absolutely nothing” (Le Carré, Tinker, Tailor, Soldier, Spy 80). Ultimately, Smiley does not take action to save his marriage and instead continues with his routine of a spy serving his agency and county, but ignoring himself in the process.

As with England, and Karla and the Russian mole, Ann is part of the puzzle Smiley is trying to solve. She is often recalled only in Smiley's memory when he is alone, at his most vulnerable, in conversations where he is quiet, observant while she is vocal and declarative. At the beginning of their relationship, “[Smiley] thought that Ann was his grand coup, a validation that he was a worthwhile person in a lonely, hostile world. When Ann first leaves him, he becomes a joke that people soon forget about, the 
toad that had married the beautiful Ann Sercombe. She will return to him and leave him over and over again” (“Alphabetician”). As with England, Smiley’s relationship with Ann is not perfect, but all they have is each other. It's either that or oblivion: the cold. Holly Beth King, an early critic of Le Carré's work, suggests that while Smiley’s love for Ann is his "greatest vulnerability," it is also "what preserves him as a hero in a world of ultimate betrayal" (King 89).

In George Smiley, John Le Carré set out to create a character that was not to be defined by a social class nor fit a specific generation. Smiley was made to be a character committed to the center of political tensions. This commitment to neutrality will become the "new" Smiley’s greatest asset as he seeks to reinvent himself in the process of saving the Circus. The "old” Smiley sets out to save Camelot, and in the process the dignity of England and his relationship with Ann. But Camelot, England, and Ann all represent a past marred by failures and the rejection of change. The new Smiley will need to transcend these failures and position himself not as the savior of an old idea, but as the promoter of new philosophies which have to include sharing more information with American intelligence agencies and accepting the fact that intelligence work is measured in results and not on the sacrifice of a single man.

England, for the purposes of the "new” Smiley, can be used interchangeably with the Circus since the policies of one entity shape the ideology of the other. Therefore, it is appropriate for Smiley to have set out on his quest, but unlike the mythical King Arthur, he must reject the possibility of a restored Camelot. Instead, Smiley should focus on building a new Camelot, one that embraces change and promotes a culture of dialogue 
and discourse. When it comes to England as the insignificant middle-man, the "new" Smiley can reshape the country's position in global politics by placing England strategically as a mediator and define its role on the global political stage instead of siding with the United States and its already-defined policies towards Soviet Russia. In order for him to accomplish this, Smiley needs to regress to his roots as a scholar and promote, once he is in charge of the Circus, his humanitarian credo. ${ }^{19}$ This would allow England to separate itself from a reluctant, servile mentality towards the United States that causes continuous tensions and disenchantment, especially among those in the British intelligence service.

As a reader, if one considers the "new" Smiley a post-structuralist construct, part of the binary composition of the character as a whole, then it can be concluded that the "new" Smiley should acknowledge and accept that the current state of England and the Circus is outdated and retrograde in its approach to dealing with the rising threat of Communism. The reason for its present state and decay in prominence is the result of mounting failures in the policies that were implemented over the years after World War II. Those policies left England and the Circus dragging "like condemned prisoners, as ideologies do when they’ve had their day” (Le Carré, Tinker, Tailor, Soldier, Spy 195). ${ }^{20}$ Smiley explains his position regarding the current state of the Circus and reaffirms why

\footnotetext{
${ }^{19}$ According to John L. Cobbs , Smiley is considered a character who focused too much on decency, patriotism and humanity. These are traits readers may not normally associate with spies. One who always had an "urbane upper-class aura of good manners about him.” This is in contrast to Alec Leamas who a "Circus ‘fieldman,' a nuts-and-bolts agent who works in enemy territory” (Cobbs 46).

${ }^{20}$ The implementation of a socialist program, the decline in production, dependence in foreign monies, and the loss of colonies left many English people wondering about the fate of their nation and their future in world politics.
} 
he should be in the middle ground, along with England, since ideologies "have no heart of their own. They're the whores and angels of our striving selves" (Le Carré, Tinker, Tailor, Soldier, Spy 196). He continues his condemnation of the State as an architect of policies that are sometimes too large to handle. Smiley concludes his condemnation of the State by acknowledging that "it's the over-mighty modern State we've built for ourselves as a bastion against something that isn't there anymore. We've given up far too many freedoms in order to be free. Now we've got to take them back. So while you're out there striving loyally for the State, perhaps you'll do me a small favor and lean on its pillars from time to time. It's got a lot too big for its boots of late. It would be nice if you would cut it down to size" (Le Carré, Tinker, Tailor, Soldier, Spy 205). The allusion to the size refers to the past, when England was the center of a sprawling empire but in a different political world.

Another aspect Le Carré presents of the "new" Smiley, and which the reader ought to accept, is his decision to stay separated from Ann. It is acceptable that Ann represents stability and comfort for the "old” Smiley; however, she is also an anchor of emotional failure and continuous sentimental disillusionment. In one instance, after two years of marriage, Ann decides to leave Smiley for a Cuban ${ }^{21}$ race car driver. For the reader, it should not be a surprise that the man she replaces Smiley with is a Cuban national, a close ally of Soviet Russia at the time, by default making him a Communist, thus extending the post-structuralist dichotomy to a personal level. Smiley should

\footnotetext{
${ }^{21}$ The "Cuban racecar driver" is perhaps the ultimate symbol of the Cold War era. He is a man of passion and freedom, and by choice a risk-taker. He embodies libertine and youthful passions of the 1950 - 1970s: racing cars and a following for Communism as a way uniting people and rejecting the rising influence of American hegemony and its consumerist mentality. He is also a stark contrast to George Smiley.
} 
understand that his relationship with Ann is in the past, and must remain there. Ann, by choosing to run away with a Communist, is rejecting everything that Smiley is as a man and a professional and everything he stands for. In contrast to Smiley and the Circus, she is running away with a man who follows adventure, pursuing a revolutionary ideology, and is essentially what Smiley never was. By wanting to reunite with Ann, Smiley shapes their relationship into a circle of emotional dependence that needs to be broken. What Smiley must do is embrace his alienation from those who prefer and follow certain ideologies, and reject Ann as a symbol of dependence that binds him to the paradox that has shaped his life.

However, with all the flaws and complaisant nature of the "old” Smiley contrasted with the more pragmatic and forward-thinking "new” Smiley, the text rejects the idea of portraying George Smiley as separate halves with opposing ideologies. As much as the "old” Smiley would valiantly stand up for England and restore Camelot, he would inevitably die in his quest. In contrast, a “new” version of Smiley would never compromise England's proud history, or move on from his relationship with Ann. Otherwise, he would cease to exist as well. Smiley's predicament is best interpreted through Peter Guillam, a young spy who decides to quit the Circus after seeing what happens to spies following years of service. He contemplates Smiley’s Dilemma: "One day... one of two things will happen to George. He'll cease to care or the paradox will kill him. If he ceases to care, he'll be half the operator he is. If he doesn't, that little chest will blow up from the struggle of trying to find the explanation for what we do” (Le Carré, Le Carré, Tinker, Tailor, Soldier, Spy 27). Le Carré created Smiley to be the sacrificial team 
player, one who would bear the paradigms of England and the Circus in the interest of the greater good. He is the hybrid of a romantic and realist, sacrificing himself to uphold the pillars of Western society, an individual whose private morality constantly confronts institutional necessity, a committed doubter, and a disgusted patriot (Aronoff 18). In Smiley, Le Carré personifies the possibilities and disillusionment of espionage.

In all the novels in which Smiley appears, there are clear indicators of internal conflicts. He is a man who struggles when it comes to defining and accepting the role he plays to others and to himself. However, in Le Carré's world of binaries which include an emphasis on good \evil, Communism\Democracy, institution\individualism, loyaltylbetrayal, and East\West, "Smiley [...] is the only character who can stand between two worlds and, if not reconcile them, live with the opposites thrust upon him by life" (Panek 33). In “Tinker, Tailor, Soldier, Spy,” he is able to ultimately root out the Soviet mole, Bill Haydon. But in achieving his goals, he loses himself by becoming head of the Circus and staying separated from Ann. As Smiley treads between two worlds made up of old ideologies, new approaches, and paradigms, he also loses the humanity he once possessed. "All that he is left with is his painful consciousness” (Le Carré, Tinker, Tailor, Soldier, Spy 106).

Another reason why the text discourages Smiley’s divergent views of ideology is because if he decides to maintain and “old” philosophy, or adopt a "new” approach toward achieving his means, he would be ineffective. In order for him to remain the spy he is, the "hunter, recluse, lover, solitary man in search of completion, shrewd player of the Great Game, avenger, doubter in search of reassurance,” he must remain in the cold, 
where other people like him live and thrive. For Smiley life is about duty; it has shaped his character and defined his existence. Therefore, the question that arises is: who is the real George Smiley? He is what intelligence service officers should be - observers, actors, voyeurs of the political circles - but he is not what intelligence wants him to be. In Le Carré’s novel, “A Murder of Quality” (1962), Smiley confronts and condemns Karla over his role in placing the Circus' mole, but inadvertently in his accusatory statement, he ends up talking about himself:

"And there are some of us, aren't there, who are [...] nothing, who are so labile that we astound ourselves. We're the chameleons. I read a story once about a poet who bathed himself in cold fountains so that he could tell he actually existed from the pain of it. [...] People like that, they can't feel anything inside them: no pleasure or pain, no love or hate. They're ashamed and frightened that they can't feel, and their shame, this shame, [....] drives them to extravagance and colour. They have to feel that cold water. Without it, they're nothing. The world sees them as showmen, fantastilists, liars, as sensualists perhaps, not for what they are: the living dead." (Le Carré, A Murder of Quality 124).

At first, Smiley rejects the language of projection, of excluding himself from those who are void of emotions and ashamed for they committed while undercover. However, Smiley cannot avoid including himself in the same group of spies like Karla since he has lived with loss of love and "anger," and like an old illness, "he had been denying its existence, steering away of anything that could touch it off: newspapers, former colleagues, and rumors” (Le Carré, Tinker, Tailor, Soldier, Spy 79). 
When it comes to addressing the dichotomy of past/future in "Tinker, Tailor, Soldier, Spy,” both sides of Smiley need each other in order to find the flaws and strengths in one another and to survive. Linguistically, Smiley's existential scathing barrage toward Karla is a statement that profoundly characterizes him as he moves from an inclusive first-person "some of us," to a distant, full-of-disdain third-person pronoun reference to "people like that," the ones who need to stay in the cold. Those of course are “the living dead” (Le Carré, Tinker, Tailor, Soldier, Spy 212). The shift in point of view captures the struggle Smiley has always lived with. He has always tried to be one of 'them' while attempting to keep the essence of what makes him human, the qualities that make him George Smiley. But the use of the word "cold" again becomes a signifier for what the intelligence service is for Smiley as it was for Alec Leamas in "The Spy Who Came in From the Cold” (1963). The cold is reality. The cold is what embraces spies in their careers with all their idealism, flaws and ambitions. It is a dualistic, paradoxical place of existence that slowly kills them while making them feel alive and complete. Like Leamas, Smiley cannot come in from the cold and regain his sense of self outside of the intelligence service. Retirement for Smiley, as it was for Leamas, has never been an option.

Ultimately, in “Tinker, Tailor, Soldier, Spy,” Karla becomes a symbol that validates Smiley’s quest. "Karla was the proverbial cold-war orphan. He had left home to do a job abroad. The job had blown up in his face, but he couldn’t go back: home was more hostile than abroad. [...] So it was up to Karla to ask us for protection” (Le Carré, Tinker, Tailor, Soldier, Spy 210). Paradoxically, Karla becomes the confirmation of 
Smiley’s beliefs. Smiley and Karla, initially portrayed as ideological opposites, exchange places and are transformed into images of one another. Through their morphing, the reader is able to clearly observe both, the "old" and "new" Smiley, but more importantly, understand his need to remain in the same place as Karla, in the cold, where all spies end up but where he at least retains his essential decency and character. The price Smiley will have to pay for victory - anger, solitude, and the realization that "he never was and never had been indispensable" - make it a very bitter, if not pyrrhic, one for him (Le Carré, Tinker, Tailor, Soldier, Spy 79). Lynn D. Beene suggests that The Karla Trilogy, beginning with “Tinker, Tailor, Soldier, Spy,” "unites Smiley’s halves and terminates him” (Beene 95). Through three novels, Smiley professes an undying belief in the power of Western democracy, in the superiority of moral means over questionable ends, in the permanency of intellectual ideals, and in attaining possible salvation through love. However, at every step, he fears these decencies are illusions.

Once the quest comes to a close, and Smiley stays as Control, or head of the Circus, he reflects on the political and personal challenges he has dealt with throughout his journey and continues to face. Undoubtedly, he realizes the challenges of preserving the past along with facing and adapting to the future changes in espionage will continue for him as they do for all spies. In his role as a savior, he typically encounters these demons and revelations in order to test his moral fabric and validate his success after overcoming the struggles. However, in “Tinker, Tailor, Soldier, Spy,” Le Carré presents all the challenges and struggle of a Medieval Romance quest, but does not validate Smiley as a hero. For the reader, however, Smiley serves as an exemplary role model for 
the heroic struggle to achieve a balance between conflicting ethical and political imperatives, competing loyalties, dreams and reality, ends and means, optimism and pessimism. But heroism works against Smiley as much as it works against the text. Le Carré and the text reject accepting Smiley as a possible hero that deserves recognition, and in the process of saving the Circus, Smiley found out more about himself than he may have wanted to know.

Heroism, as Le Carré's texts imply, should be left for others. Perhaps there is no greater contrast to James Bond than George Smiley. In fact, Andy East suggests that "Le Carré’s Secret Service protagonist, George Smiley, signifies a contemptuous revolt against Bond" (East 170). Le Carré states that the character, James Bond, as literary champion from the early period of the Cold War, "was an absolute travesty of reality; it was an absurdity and a vulgarity" (East 171). Le Carré has written that, "Bond himself would be what I would describe as the ideal defector. Bond, you see, is the ultimate prostitute. He replaces love with technique." Bond, unlike Smiley, "has developed a pretty hard-nosed cynicism towards any sense of moral obligation," with his attempt "to remake a figure who was involved in the dilemma of our time: we are sacrificing the individual in our battle against the collective" (Aronoff 38). Le Carré considers this moral cynicism a reflection of the worst aspects of contemporary Western society.

Yet, Smiley’s loyalty and inability to sustain hatred toward those who have betrayed him, and his resolve to act despite serious reservations about the consequences of his actions, are precisely what make him a flawed, tragic, but heroic figure 
nonetheless. Andrew Rutherford contrasts Smiley, who "lives in practice by a code of loyalty, of fidelity, of obligation," to the mole, and suggests that they,

"Emerge as representatives of integrity and corruption in a world of crumbling values, which can be sustained, it seems, only by bleak courage and loyalty without much faith. "Tinker, Tailor, Soldier, Spy” implies a sense of faith--not so much in a country or political system (though Le Carré's preference is clear), as in the man himself--in his capacity to live humbly, yet heroically and sacrificially, a life of service." (Rutherford 154).

At the end of “Tinker, Tailor, Soldier, Spy” Smiley does not reinvent himself, nor does he stay the same. He remains a vulnerable man in a vicious world, who, even though is contaminated by the deception that surrounds him, is not entirely destroyed by it. "For all his faults, he seems genuine though that is another illusion, for he is a fiction, albeit an immortal one and one made in the image of a real man” (Bold 22). Smiley is usually able to keep a delicate balance between his duty to the Circus and his moral obligation to be human. He repeatedly warns the young spies of the high price their job will cost them-the truncation of their natural feelings leading to the death of their Self that results from the manipulation of their fellow men. These are the consequences of what he terms a life withheld: "The end may justify the means--if it wasn’t supposed to, I dare say you wouldn't be here. But there's a price to pay, and the price does tend to be oneself" (Le Carre, Tinker, Tailor, Soldier, Spy 210). It is this awareness of sacrifice that finally unites Smiley’s “old” version and “new” version and keeps him alive. 


\section{WEAVING A LIE}

“The Tailor of Panama” (1997) is a voyage into the mind of a spy. Most importantly, the novel is an attempt to reveal the moral fabric of the individual spy as he manages loneliness, hubris, and the temptation for self-indulgence and betrayal. These are just some of the effects and consequences of the profession. By utilizing Panama and the canal as a setting, the novel offers an intimate look at how spies operate and behave when they are in the field. Leaving the confines of London and the Circus, Le Carré sets his novel around an international landmark whose rich history and cultural diversity of labor and engineering helped create what has become a crucial passage for international commerce. The physical structure helps unite two oceans, various interests as well as ideas. As a bridge of sorts, the canal allows for shorter passage between two oceans as well as two characters that are very different, yet share similar humanist elements as reflected in the text. As a symbol in the novel, the Panama Canal holds the collective conscience of all the characters. On the one hand, the narrative function of the canal is to allow two particular characters, Andy Osnard and Harry Pendel, an opportunity to reach personal goals which will elevate them beyond the flawed individuals they are. On the other hand, the canal also prevents characters such as Mickey and Marta - true Panamanians - from having the opportunity to help their country transcend its troubled history and emerge as an independent and significant center of commerce in the region. For Harry Pendel, the novel's namesake, “the canal has led to a better, more stable life in which the past no longer haunts him” (Le Carré, The Tailor of Panama 21). And for the spy, Andy Osnard, the canal is the gateway to "El Dorado of every British espiocrat [...] 
where officers of [his] talents can make a name for themselves" and find redemption as a British intelligence outcast (Le Carré, The Tailor of Panama 203). In essence, the canal plays a central role in establishing the textual hierarchical relation between the spy and the tailor.

The novel starts with an MI6 spy, Andy Osnard, reassigned to Panama after having an affair in Madrid with the foreign minister's wife. In a briefing with his superior, Osnard is warned of the corruption, and given established contacts he can rely on in case he finds himself in the middle of the political chaos engulfing the country after Noriega's ousting. Osnard begins to see Panama as an opportunity. In Panama, Osnard meets Harry Pendel, the tailor of many of Panama’s elite, including the President. Pendel is married to Louisa, an American working as the assistant to the administrator of the Panama Canal Authority. After blackmailing Pendel with exposing his criminal past, Osnard convinces him to work for him and help him establish a network of spies, provide him information about Panama's elite, and inform him of the transitional proceeding of the canal. After a few exchanges of information, and finding himself under pressure for more valuable information, Pendel starts tailoring his outrageous stories to keep Osnard happy. He makes up a story that the canal will be sold to the Chinese, to both, Beijing and Taiwan, and that there is a mounting rebellion on the government if the sale of the canal goes through. In return for his information, Pendel receives large sums of money to continue his own façade as a prestigious tailor and promising rancher. However, the money he makes is to cover the debt he has as a result of bad investments with Louisa's money and farm. After Pendel realizes Osnard keeps asking for more details, he decides 
to quit spying saying the rebel group, the "Silent Opposition,” needs more funds, $\$ 10,000$ to be exact, a figure high enough to dissuade Osnard from pressuring for more intelligence. However, once Osnard receives the money from England, he runs off with the money and leaves Panama. Eventually, Louisa finds out what her husband had been doing and he is forced to explain everything and continue his normal life as a tailor.

“The Tailor of Panama” introduces the reader to a charismatic tailor and a spy of questionable professionalism. The text presents multiple conflicts and dichotomies, but the opposing personal interests of Andy Osnard and Harry Pendel are what define the story. Although each character has internal, professional, and personal problems to address, it is the dynamic opposition between both characters the text utilizes to drive the narrative and explore individual struggles in the human condition. Harry Pendel is described as a British expat who works as a tailor for the social and political elite in Panama. He is accomplished in his craft and has adapted quite well to life in his new country. Although his past is mixed with charges of fraud and a brief prison sentence in England, he has managed to find a niche social position in a country that is still undergoing a transformation from the days of the dictatorship of Manuel Noriega in the 1980s. On the surface, Harry has managed to build a life in Panama that serves as an example for his children, and finally allows him the opportunity to be a good husband and family man. Alternatively, Andy Osnard is the British spy who visits Panama on official business under the cover of Britain’s renewed interest in reopening the country’s intelligence operations. Although the British interests in Panama are a fictional construct of economic and political nature, in reality, Andy is in Panama as an outcast. His position 
as British embassy personnel and intelligence leads are fabricated to help him find absolution for himself.

"The Tailor of Panama" can be described as a chronicle of the struggles facing new democracies. Panama is a nation coming of age, and the canal being handed over from American control to Panamanian authorities is a rite of passage into sovereignty. But “chaos is the precondition of democratic awareness” (Le Carré, The Tailor of Panama 140). Le Carré takes advantage of the transition process and the presumed socio-political chaos that may ensue, and places Andy in a place fitting for spies. In this complex setting, the novel portrays Andy as a spy without principles or morals. He has come to represent the dangers of espionage by ignoring all professional and ethical implications his actions may have on others. In the novel, Andy has chosen to follow his personal philosophy and has decided to work for individual gain and financial benefit, and Panama provides him the right opportunity.

For Le Carré, Andy completes the descent into the trappings of espionage. As stated earlier, he is a washed-out spy who has been sent to Panama as a means of preventing British and Spanish tensions from escalating due to his romantic escapade with the Spanish ambassador's wife. As a spy, he has been exiled to the Purgatory in Central America where he will join other British outcasts. The cover for his exile is to monitor the canal's transition process and ensure that the canal does not fall into the wrong hands. For Andy, Panama provides an ideal setting because it is a place where morals and values have not been established and where political savagery and economic opportunism are still accepted as the norm. This backdrop allows the text to rely heavily 
on Andy's keen eye to judge men, and places the reader in a parallel position with the spy, where Andy is free to explore and exploit the corrupt social and political landscape of the country. From the beginning, the novel places Andy as an observer of men, and elevates him to a position of power and superiority, not just intellectually, but in worldliness. He is the voyeuristic spy, analyzing people and trying to understand them in their natural environment in order to find their weaknesses and exploit them. This is problematic in the text because it empowers Andy to take the form of a new conquistador on behalf of a collapsed British Empire. In Panama, Andy is the embodiment of the British angst over their loss of global influence. In order for him to maintain power, or keep British influence in the region, he must secure the secrets of the canal.

As a British spy, Andy allows the reader the opportunity to explore another typical theme in many of Le Carré's novels: the role of England in international politics. Up to the transfer of the Panama Canal, the structure had always been under American control since it was completed in the early 1900s. Therefore, the reader must question what interests does Britain have in the transfer of the canal, or the Panama Canal itself? As an intelligence officer, Andy provides the answer by bluntly stating: "We have no interest in Panama. Panama is a backwater. Panama is two men and a dog and let's all go have a good lunch” (Le Carré, The Tailor of Panama 203). But despite Andy's, and by extension England's disinterest in the canal's future, the Panama Canal serves as a site for the representational struggle of the British intelligence agency trying to remain relevant in contrast to the rise of American intelligence. Therefore, Andy fabricates and convinces his countrymen of the idea that the Panama Canal will fall into the control of 
the Chinese, and out of the hands of the Americans, without London being aware. Again, this becomes a symbolic lament by Le Carré regarding England's decaying influence in the international stage.

As the novel develops, Le Carré begins to expose both characters' flaws. Andy is the shamed, opportunistic spy who has been exiled by MI6 to Panama, and Harry is the outcast convict searching for a new life. In this regards, the text favors Andy because he is the spy who appears to come in as a rescuer of Panama. This proposal of salvation further strengthens the role of Andy as conquistador, setting him up to secure new treasures, and he pillages only the valuables of the New World. As a spy, the text places Andy as a seer of man and character, one who is able to see "the false nature of human beings” (Le Carré, The Tailor of Panama 60). However, Panama is a very complicated country and in contrast to the "primitivism" of its people, the novel places too much emphasis and credibility in Andy and the way a flawed character experiences the country. After arriving in Panama, Andy usurps the role of a member of high society and freely uses the Circus' financial assets to establish a network of spies willing to work for him in the name of Britain. Ideally, Andy needs an insider, one who is capable of providing access to sensitive information and is susceptible to manipulation. A person that will show him and introduce him to the local social and political figures who "are willing to sell the country to the highest bidder (Le Carré, The Tailor of Panama 4). In his search, Andy encounters the classy and sophisticated tailor who appears to have an established life in Panama. 
For Andy, life in Panama as a spy becomes a constant struggle of living between two masters. First, as an individual he must serve the agency that employs him while attempting to address his needs, mainly his greed and self-indulgent lifestyle that betrays the nature of espionage. The problem with Andy is that while in Panama, he is neither honest with himself nor the Circus. Rather quickly, his old work habits begin to overtake his individuality and morality. Andy, through a system of repetition and reinforcement ${ }^{22}$ of a fabricated reality, begins to betray himself and his employer, thus creating a downward cycle of moral and ethical disloyalty that destroys most established human relationships. Le Carré's choice of character, in this case Andy, is selected for expressing this model of individual vice and as the agent that attempts to satisfy two parties: the betrayed employer and the self. For Andy, this consortium of lies and constant repression of basic human values leads to a life of isolation, moral wash-out, and even suicide. Life no longer has a purpose, because Andy has forgotten what "reality" is about, or how to be part of a greater, common society.

In contrast to Andy, the text places Harry Pendel as a spy asset for Andy. From an operational side, this alliance makes perfect sense because "everyone in Panama knows Harry” (Le Carré, The Tailor of Panama 53). But the text does not provide much opportunity for Harry to reject the offer of spying for Andy. Arguably, Harry was blackmailed into espionage, but as a character seeking to reform his life, he had very little chance to reject Andy's offer. Furthermore, Harry should have no interest in spying for England considering he had served a prison sentence and fled to Panama to start a new

\footnotetext{
${ }^{22}$ This system of reinforcement is the creation of a lie, as representative of truth. However, the truth never exists. Therefore, a constant, systematic set of lies and fabrication must be set up in order to create the illusion of truth.
} 
life. By presenting characters whose paths seem to be similar, the text presents the opportunity for Harry and Andy to clash.

Although Andy is the spy in the novel, he has no control of intelligence networks, or information regarding the transfer of the canal. Normally, it is the spy whom the reader can trust with completing his mission by having access to tools and information. But in “The Tailor of Panama,” through Andy, the true nature of espionage begins based on manipulation and betrayal begins to reveal itself. The character of the spy is an inherent contradiction found in the text, or the aporia that exists in the intelligence service. Historically, he is the individual who has been a great manipulator of people and secrets but who may end up believing his own schema of lies and illusions designed to guard secrets and his identity. He is also endowed with state secrets so sensitive to political structures that the secrets themselves become a destabilizing force for the individual, since ironically, the secrets guarded by the spy are unknown to him. In fact, as most Le Carré novels point out, the spy is the least aware of a situation in which he is involved. In the case of Panama, Andy is the spy, but the one manipulating the intelligence is Harry Pendel, who can arguably be considered the main character. He acts as the narrator who early on in the novel demonstrates the moral righteousness of a model citizen. He is a family patriarch and accomplished businessman. However, the novel quickly begins to offer two alternative ways of looking at Harry: 1) as a failed businessman and 2) as a con artist. Through Harry as a narrator, the text lays the scene of Panama as a country characterized by the hustling and bustling of a large metropolitan city, with the shrieks of sirens, grunts and grinds of bulldozers, yet all the "farting and protesting of a third world 
tropical city that can’t wait to choke itself to death” ${ }^{23}$ (Le Carré, The Tailor of Panama 5).

With this setting, Le Carré sets the tone and expectations of what a character that lives here would be like. However, the text contrasts the image of a dirty and chaotic city with the clean and precise work of the tailor. He is the owner of a shop that traces its lineage to the luxury rows of London, and in Panama is the "tailor of royalty" (Le Carré, The Tailor of Panama 29). At this point in the novel, the word "royalty" creates an ambiguity in the role of Harry: royalty implies noble birth and royal lineage, none of which are present in Panama. The implication of royalty appears to be a mockery of the British crown in relation to the irrational role Britain is playing in the country. But considering the nationalistic tone of the characters in Le Carré's novels, it is safe to assume that the implications of royalty for Harry, like Andy, have a carte blanche at exploiting the people and politics of this country. Therefore, royalty is used in the text as a rather subtle assumption of Harry’s status in Panama. Royalty also serves as a point of reference and certification of creed and trust for Harry. By virtue of Harry’s being British, the reader is lead to believe that Harry has credibility in his word and actions, which is a lot more than can be said about the traditional Panamanian citizen, as presented in the novel.

The text places significant authority in Harry, and “The Tailor of Panama” reaches moments when the narrative adopts a self-referencing position, creating a series of signs that help elevate its meaning as a whole. Starting with the title, one assumes it

\footnotetext{
${ }^{23}$ It is important to note that Panama, as described by Harry is not entirely accurate. Panama, based on social indicators, is placed closer to an upper-middle-class Latin American nation such as Argentina and Uruguay (Falcoff 24).
} 
refers to the job performed by Harry, as the namesake of the novel. But in fact, the narrative attempts to portray “tailoring as the act of improving people” (Le Carré, The Tailor of Panama 62). More precisely, tailoring often involves shaping people to conform to their rightful place in society. Harry is the character who beyond fabric and lies, is able to singlehandedly reshape the moral fabric of Panama, one suit at a time. Tailoring is a way of improving people: "It [is] cutting and shaping them until they become members of his internal universe” (Le Carré, The Tailor of Panama 62). Most importantly, tailoring for Harry involves "making people bigger or smaller according to whether they enhanced or threatened his existence” (Le Carré, The Tailor of Panama 62). Because of his tailoring skills, the text elevates Harry as the narrator of the human condition in Panama as well as the voice of how to tell the story of tailoring people. Once elevated to an authorial figure within the narrative, Harry becomes a guide who demonstrates the practical ways people can improve upon themselves. Tailoring, in this case represented by Harry, can be performed on the finest fabric for any individual, but society cannot be shaped by one man’s vision. Therefore, for Harry, tailoring also becomes a process of rediscovering his own virtues and a way of finding a meaningful purpose and validation for the life he has created.

In his effort to improve the political elite of Panama, the text presents Harry as the 'great spy.' Ironically, in the political circles of Panama, the tailor has more manipulative power over people and secrets than the professional spy (Le Carré, The Tailor of Panama 129). Chapter eight is the shortest chapter ${ }^{24}$ in the text and juxtaposes Harry and the

\footnotetext{
${ }^{24}$ Chapter eight, the shortest chapter in the novel, functions as a voyeuristic look, a quick peek by the reader, into the conversation between the tailor and the President of Panama. The conversation takes place
} 
President of Panama in the most private moment for both characters: a fitting for a suit. But the text builds up the encounter with superfluous references and adjectives which help describe the President. He is referred to by his staff as "His Supremacy", "Immortal One”, “His Immensity”, “His Excellency”, “World’s Greatest Leader”, “Master of the Earth”, “Lord of the Universe”, “Grand Master of Panama’s political chessboard”, and in the fitting, the tailor plays with his waistline, adjusting his trousers' length, and elevating his pants, making him look like Charlie Chaplin (Le Carré, The Tailor of Panama, 131). Harry's authority lies mainly within his craft:

A suit from me is not a drunken scream. It's line, it’s form, it's rock of eye. It's silhouette. It's the understatement that tells the world what it needs to know about you and no more. If somebody notices a suit of mine, I'm embarrassed because there must be something wrong with it. My suits aren’t about improving your appearance or about making you the prettiest boy in the room. My suits are not confrontational. They hint. They imply. They encourage people to come to you. They help improve your life, pay your debts, be an influence in the world. (Le Carré, The Tailor of Panama 272).

But Harry's words are also important in helping the reader differentiate him from Andy, who only provides empty, illusory discourse of grandiose foretelling. The text places further emphasis in its effort to create a detailed characterization of Harry and his surrounding in order to validate his role in Panamanian society. Le Carré goes as far as to connect him to Old England by linking his tailor shop and ancestry to one renowned

in the president's chambers with no one else around. Symbolically, the sarcastic revelry and admiration by the tailor serves to establish him as the authority figure in the scene and deductively in Panama. 
institution in London, Pendel \& Braithwait, whose previous owner, Harry’s uncle, dressed the elite and entitled of high-society London. Harry brings out his own expertise and culture by recommending and working only with the finest materials. As a tailor, Harry is elevated to a status of redeemer by Andy. After circumventing the circles of Panama's elite, Andy cannot help but admire the skill, with which Harry traces the political minefield and corruption of the social elites. This skill of tailoring people allows Harry to become the more qualified character to redeem Panama, not Andy. But like Andy, Harry is also looking to benefit himself from Panama.

To a certain extent, the contrast created by the text between Harry and Andy is invalid. Both characters, although set as binary opposites in the novel, need each other in order to succeed individually on their missions. By Harry becoming a spy for Andy, he becomes the supplement for British intelligence in Panama. And just as Andy fabricates the intelligence for the Circus, Harry can tell quite a few stories just as convincingly. Andy and Harry both form a mutually beneficial relationship based on lies. As Andy needs some kind of new intelligence to justify his existence, he initiates his interaction with Harry as a kind of game based on lies and grandiose imagination. Their relationship is built on Harry providing Andy with suits and information, Andy provides Harry financial compensation in order to keep the relationship working. This relationship, in which Harry resides in the words of Andy, forms a type of "invaginational relationship," that according to Derrida, is where one sign exists secretly within the other (Dooley and Kavanagh 33). What Andy lacks in ability to shape people for his purpose, Harry provides in his tailoring of individuals to bring out their true personal being. Without Harry, Andy would be a shamed British spy on the "shelf" in a country he likes to refer to 
as hell. And without Andy, Harry would be another disgraced British expatriate roaming the circles of liars and thieves in Panama. If the tailor is the one who shapes the spy, money is what shapes the tailor. Therefore, to assume that "The Tailor of Panama" favors Andy over Harry or vice-versa would be unfair to either character. Both characters have lived a life of lies and treason, and in Panama, they search for a reason to justify their existences. The novel juxtaposes both Andy and Harry by uniting them in a country where they can continue to pursue a life of lies. Although each character went to Panama for separate circumstances, both Andy and Harry belong in the country. Harry's profession and masterful tailoring skills do not elevate him from a character that is trapped in his own lies. The political affiliations and his business are not enough to leverage the fact that his pre-Panama existence is completely manufactured and unknown to his wife, Louisa. Only Andy knows his secret. Harry learned his craft and mastered his tailoring skills while serving a prison sentence for insurance fraud, placing him in a prime position to be in contact with the powerbrokers in the country all that way up to the President of Panama. He understands the country and knows the people because he can relate to them.

One element "The Tailor of Panama” leaves out is the notion of heroism. Instead, for much of the novel, it tilts the humanist balance in favor of power and decadence over truth and morality. The only heroes introduced, but never developed, are characters who symbolize the social state of Panama. Mickey and Marta can see beyond their own interests and are able to decry the greed and corruption of those in power. However, if the characters would have been developed, they would diminish Andy and Harry's influence 
in the text, undermined their roles in Panama, and weakened the structure of the novel as a whole. In Panama, heroes lurk in the shadows, the only place where honor and justice are to be found.

Panama is a country where real heroes have no faces and their voices are silent. By all accounts, heroism is a constant struggle between the individual's needs and the needs of the collective. “The Tailor of Panama” rejects Harry and Andy as heroes. As spies, they live without a philosophy, and seek self-reward as the ultimate goal in life. Such lack of direction and self-deception makes them unfit to meet the needs of others. In "Superman on the Couch,” Danny Fingeroth writes, “A hero embodies what we believe is best in ourselves. A hero is a standard to aspire to as well as an individual to be admired” (Fingeroth 14). For the normal individual, there is a need to look up to something and beyond the self in order to aspire to something greater. Normally, the hero is idolized for renowned deeds, and for accomplishing goals that will benefit the greater good. However, for the spy and the secretive nature of the profession, exposure to the public would likely mean imprisonment or death. The spy already sacrifices mind, self, family and all the pleasures of being human in order to pursue ideals that may even be unknown to him. For a spy, then, being a hero - or an unsung hero - becomes a burden. Ultimately, the spy as a hero ends up having to completely deny his individual self in order to fully be able to accomplish his mission. The text does not elevate Andy or Harry to this level, and neglects to do so with Mickey and Marta for structural reasons. Elevating them to the narrative forefront would create a power struggle between the locals and the foreigner, thus diminishing Andy's role and purpose even further. If Panama had heroes, the 
country would be a different place and socio-political stability would be achieved along with morals and values.

However, in Le Carré's vision of Panama, heroism is not constructed on the premises of good versus evil, nor is it a positive value added to the story. The kinds of heroes found in the novel are outcasts and marginalized individuals inhabiting the outskirts of the burgeoning circles of a corrupt society. The book introduces Mickey and Marta as the last true revolutionaries left in Panama. But they are not mentioned in heroic roles or as nationalist patriots that can help shape the next generation of Panamanian leadership. Instead, they are portrayed as individuals with the quixotic illusions of the oppressed and hopeless. Now, they are silenced voices that once spoke of a better country.

In the novel, heroism is masked with deformity and liquor as if Le Carré does not want heroes to have a voice or a face. Marta is first introduced as Harry’s secretary, a loyal worker perhaps, but a secretary nonetheless. She is further subjected to a stereotypical female role of cook, maid and mistress. Nothing to be afraid for the spy, she is a "badly scared woman of mixed race” (Le Carré, The Tailor of Panama 25). This generalized description, however, fails to capture the essence of Marta. The scars, later on explained as reminders of the torture she underwent for being an active member of a paramilitary group planning a coup d'état, are dismissed as deserved punishment. In fact, the novel implies that the scars are a lesson learned not just for Marta, but for any native Panamanian who attempts future political sabotage. The implication of the mixed race is also important to note since it is never specified which races. Such distinction allows the 
reader to interpret Marta's heritage to be a combination of indigenous bloods and black, again a reference to migrants who settled in Panama to work in the construction of the canal, or as servants of the colonizing races.

Like Marta, Mickey’s heroism is never fully explored in the novel. Mickey now finds himself as a distant memory of Panamanian pride, as one of the country's "few real heroes” (Le Carré, The Tailor of Panama 68). But the implication of heroism is lost in liquor and habitual boisterous disturbances that Mickey is engulfed in while drunk, which happens quite often. In the past, he was an activist for change, protesting corruption, communism and those who sold Panama for their own interests. Consequently, he was imprisoned and tortured, but released once Noriega fell from power. Mickey is also the leader of the "Silent Opposition," a marginal group waiting on the political sidelines to retake the country and restore it to dignity. However, the Silent Opposition is Harry’s fiction and part of his elaborate scheme to mislead Andy and British intelligence service. However, unlike the giddy patriots Harry portrays them to be, if there were an opposition, it would be made up of fishermen and students, "the people who can't get poorer without dying” (Le Carré, The Tailor of Panama 140). Now, Mickey continues to protest the "hangover,” referring to those in power who were corrupt. Both, Mickey and Marta’s acts of valor are told from the past tense, as a recollection of what was or could have been, but never with the hopes of explaining their present influence.

In the novel, 'silent' is a term of différence. Applying Derrida’s conceptual linguistic terminology to Mickey’s 'silent' opposition, the reader soon realizes there is less to this group than Andy and the British intelligence service imagines. "Silent” at first 
refers to the state in which the group is in Panama. They are not vocal oppositionists to the government or its approach to governance. Led by Mickey, they are not a group that creates violence or incites chaos. In fact, the Silent Opposition is a group that lives in the mountains. Therefore, "silent” becomes a term for absent. However, the notion of being absent would still imply that, because they are a group living in the outskirts of Panama City, and given the opportunity or need, they would still gather as a group and protest the current power structure. Furthermore, by being absent from the city and living in the mountains the group becomes inexistent when neither Mickey nor Marta, much less Andy or Harry, have access to any of the members of the Silent Opposition. Thus, the basis of Andy and Harry's spy network is constructed on the trace created on the belief of a group that will one day rise against the government, and with nationalist fervor will take ownership of the canal and provide stability to the country.

It is evident in the text that Mickey and Marta are perhaps the only heroes left in Panama, and may also be the ones who can be catalysts for change and salvation. However, the text places them as symbols in a land that the British can now exploit as they see fit. The years of Noriega, along with his dictatorship, corruption and the economy of favors, helped create a need for heroes to rise up and take Panama back. The 1989 invasion was widely seen as a sign that the United States was planning to break the Carter-Trujllos agreements. When these rumors proved false, Panama entered into an “acute crisis of identity and nationalism” from which it has yet to emerge (Falcoff 31). Le Carré plays on this national identity crisis to build a system of relationships, and brings individual prominence to his characters within the Panamanian social and political 
structure. When Panamanians realized that the United States was turning the canal over to national authorities, they turned inward to reflect on the quality of their own institutions and leadership; Panama’s political class was fragmented and disappointed (Falcoff 44). This sentiment, allows for minor characters such as Mickey and Marta to emerge, but never to develop. As with Mickey and Marta, “The Tailor of Panama” establishes a series of symbols, mostly centered on the canal, that together construct the reality of Panama. The canal also serves as a sharp divider of Panamanian society. There are those who are in charge of the country, and those who are associated with power. But then there are those people who live on the "other side of the bridge." These are the people, the "hidden rank and file, $[\ldots]$ the strivers and believers who would rather see progress than take the bribes; the decent part of Panama you never to see or hear about” (Le Carré, The Tailor of Panama, 71).

Although the novel maintains the literary complexity of "The Spy Who Came in From the Cold” (1963) and “Tinker, Tailor, Soldier, Spy” (1974), “The Tailor of Panama” adopts a tone of cynicism, intimacy, resignation, and hopelessness. The cynical tone is used throughout the novel to underline the narrative of the way people like Mickey and Marta are treated, the way Andy operates, and how espionage really works. For Le Carré, this is really what espionage is all about. In an attempt to demystify the spy and his craft, Le Carré places them in a country that fits their natural operational environment, and portrays them as individuals who just craft elaborate schemes, waste financial resources on empty ideas, and simply complicate matters more than they need 
to. In Andy and Harry, Le Carré has created two personae that are able to transmit the most compelling details of how spies and spy agencies work.

There are two unifying elements occurring in this novel. First is the complex relationship between all the characters. Second is the symbolic interaction that the Panama Canal has in relation to the characters. The two schemas created by Harry and Andy contradict each other: Harry’s scheme sees progressive ascension towards stability and redemption as well as full integration into the civilized rungs of society. Andy sees progress toward deterioration and affirmation of the corrupting nature of espionage. “John le Carré wants readers to accept his world as plausible and his judgments about the world's immorality as sound” (Beene 140). The canal, however, unites the intentions of both characters. For the text, the canal is a convenient path for both characters to find each other. The Panama Canal is also a unifying idea that binds all characters and situations. Harry finds his wife, a Panama Canal worker, and Andy finds a way of regaining professional credibility. For Panama, the canal is a "monument to the country’s powerlessness and incapacity to take charge of its own destiny” (Falcoff 30).

By the end of the novel, the institution of espionage has collapsed. The Andy is alone and fleeing from the chaos he incited. The lies about the sale of the Panama Canal are revealed, and Harry is alone, walking amidst the chaos and betrayals he helped arrange for his own gain. The images of those he lied to and used come to haunt him. Mickey, Marta, his family and friends - in his memory, they all stand looking at him shamefully as he heads into the unknown barrios of Panama where "nobody would ever again ask him to improve on life’s appearance” (Le Carré, The Tailor of Panama 400). 


\section{INTO THE COLD}

John le Carré’s novels “The Spy Who Came in From the Cold” (1963), “Tinker, Tailor, Soldier, Spy” (1974), and “The Tailor of Panama” (1997) focus on how espionage and the duties of a secret agent can have devastating effects on the individual. The main characters represent stages in the process of alienation as a direct result of their careers in the British intelligence service. These characters also represent a portion of Le Carré's personal experience, and his indirect response to the rise in global dominance of the United States after World War II. As a consequence of the changing political landscape and their duties to England, Alec Leamas, George Smiley, and Andy Osnard are forced to retreat into the cold.

The works of Le Carré, in particular the novels dealing with the Cold War, display his personal knowledge of espionage and his secret, emotional disdain toward the subject matter. Having been an intelligence service officer during the Cold War, Le Carré is able to accurately depict his characters' individualities, personal conflicts and moral dilemmas. In addition, Le Carré transcends the individual spy, which allows him the opportunity to voice the frustration and helplessness the British felt as they surrendered hegemony from their storied empire to the United States as the emerging superpower in the mid-1900s. This was a rather swift transition that shifted the landscape of international politics, and what the novels attempt to do is explore that period of transition in history from the angle of the intelligence field. In a dignified effort, the novels also attempt to demonstrate that the British intelligence service is proud of past accomplishments in its role as world leader. Ultimately, the novels become a testament 
that, even when staring at the prospect of irrelevance, Britain can carry itself proudly as always.

In his novels, Le Carré is able to capture a unique period in British and world history. In the years following World War II and the start of the Cold War, the United States played the role of rebuilder and peacekeeper in Europe. As a result, the United States found itself elevated to the position of superpower after the collapse of Britain after the war. Similar to the United States, the Union of Soviet Socialist Republics (USSR) found itself in a position vying for world power under the flag of Communism and Marxist ideals which it spread to Eastern Europe, and certain parts of the Western world. As Le Carré points out, this was a very uncertain time in world history. The rise of two superpowers meant Britain was no longer an empire, and its institutions, especially the MI6, now played a supporting role in global politics.

By creating fictional episodes based during the Cold War and the release of American control of the Panama Canal as transitional periods in history, Le Carré challenges the nature of espionage as an enterprise of exchange of information and human capital. Instead, he humanizes the profession by depicting the inner struggles of his characters, spies who are not glorified for their physical prowess or charm, but for their efforts to try and conquer the "demons" that espionage implants in their beings. Furthermore, Le Carré chooses to exempt the characters in his novels from the gunflinging action generally attributed to characters of spy thrillers. By doing this, he challenges the romantic vision of intelligence supremacy during the Cold War, and utilizes his novels' plots and characters to signal a shift toward a more polarized world capable of methodically destroying itself. 
Alternatively, John le Carré uses his novels to shed light on the declining state of espionage. In his writing, he captures the nostalgic era when espionage was more than a career path or a refined skill. He is able to reconstruct the time and conflicts when spy agencies were filed with "real" spies; people with passion, with true aptitude for the craft; people who made espionage an art form. Unfortunately, according to Le Carré, the halls of spy agencies are now filled with laments and distant memories of when agencies were finding candidates with talent and were willing to devote their life to spying. However, in his novels, Le Carré is pragmatic and capable of recognizing that spies’ ideology has shifted to a different context and purpose. For example, for Andy in "The Tailor of Panama," ideology is more about a "belief system that induces false consciousness," forcing agencies and spies to revisit their relationship in order to accomplish a common goal and follow a singular philosophy (International Bulleting of Political Psychology). In the novels, however, the separation from a common goal becomes more evident when one considers the construction and deconstruction of textual hierarchies in which the favored terms and the signifier becomes a supplement of each other. In the novels, the spy feels and believes that his place in the world is challenged by those in power (the state), thus creating a sense of exploitation and use, leaving the spy to rebel and pursue self-interest. In essence, the spy is trying to free himself from self-destruction and the exploitation from an established political and ideological system. However, one of the concerns with espionage that Le Carré brings to light in novels, such as "Tinker, Tailor, Soldier, Tailor, Spy," “The Spy Who Came in From the Cold," and "The Tailor of Panama," is that the spy may not necessarily pursue money, fame and glory for personal interests alone. The pursuit of these more tangible achievements, albeit treasonous, 
instead is a direct result of the "subjective disparity between what one wants and one has, but more importantly, it is a direct result of the psychological pressure that this disparity creates on moral, ethical and instrumental behavior” (International Bulleting of Political Psychology). In a way, Le Carré is able to recognize that spies need to be loyal to their craft, and spy agencies also need to demonstrate loyalty toward their spies as well.

To a certain extent, lack of mutual loyalty between spy and agency has allowed Le Carré to recreate the spy novel. Oftentimes, the reader thinks of the spy as an individual assigned to some clandestine "erratic adventures...to discover and ferret out the military moves and plans of the enemy” (Stanschfield 830). But in fact, this is social misconstruction built on the unknown details of the profession. Romance, as Le Carré portrays in “The Tailor of Panama,” has been eliminated from espionage, as it has been eliminated from war by scientific innovation and militaristic organization. Today, espionage is a "prosaic and systematic, business-like occupation” (Stanschfield 830). Some of the truths and lore remain in the field, but not enough to portray the profession and the agencies as some omnipresent entities able to shape history as they might have during the Cold War. Nor does the profession have the alluring mystique of the era.

Contextually, the novels of John le Carré are hybrid creations of morality and adaptability. He sometimes weaves his tales between void romantic encounters and his characters' quest for self discovery, while experimenting with modern-time conflicts of a social and political nature. For the latter part of the $20^{\text {th }}$ century, Le Carré has been able to eliminate the fantasy aspect of the spy novel and make it realistic and meaningful to the readers who want to envision a different perspective of modern issues. Over time, Le 
Carré has written about the decaying state of spy agencies and moral diluting of the individual spy. However, Le Carré would argue that under such circumstances, uninspired characters living in an unappreciative world, the fabrication of fragmented anti-heroes fighting battles against boredom and drudgery are the perfect mix for his novels (Beene 18). Therefore, it is easy to understand how in his novels nobody wins, because for Le Carré, in espionage, there are no possible victories.

In his novels, Le Carré ultimately redefines the spy with his unique style for storytelling and narrative intricacies. He gives life to a character different from that one whom society views as the decadent personification of the adventurous risk-taker sacrificing himself for international peace. Normally, the spy is the person we glorify in books and films as the adventurous character we want to be growing up. We base this vicarious attitude on the existential shell of the individual whose virtues are defined by their actions, by their skills with guns and words, and by the seductive mannerism of a professional liar. In addition, the spy is characterized by the suave demeanor under pressure, precision judgment and quick thinking. But in redefining the spy, Le Carré makes the spy into the character we would never want to become. Within modern society, the spy has been marked with artificial tendencies and aestheticism that has been deemed unnatural in the real world. This individual, of great talent and intellect, transcends the boundaries of the everyday man and moves into the realm of artificiality and abnormality. This transgression towards an elevated state of social existence, ironically, is what further alienates the spy from people leading a normal life. What John le Carré accomplishes through his characters is the rejection of archetypes, and focuses instead on morally 
flawed spies whose feats are far from adventurous and glamorous, but whose reality is more aligned to the dilemma and personal strain espionage imposes on the individual. For Le Carré, success lies in his ability to see in depth the frailty of the human condition.

In “The Spy Who Came in From the Cold” (1963), “Tinker, Tailor, Soldier, Spy” (1974), and "The Tailor of Panama" (1997) there are no heroes to celebrate. Each text rejects the notion of a man standing above a group in order to be celebrated. Espionage is a very individualized career that is more of an outward reflection of the individual rather than the prescribed guidelines of an institution. The concept of heroism, in the traditional sense, for Andy Osnard, Alec Leamas and George Smiley, would indicate that each man has his own agenda and personal interests before those of his employer. But in his novels, Le Carré is able to accomplish multiple goals for his characters. He is able to save them, sometimes from each other, and even from themselves. Perhaps Le Carré is not concerned with capturing the duality of humanity, much less the tempestuous moral dilemmas that haunt and torment the spy. He may not even be preoccupied with describing the grey area of secrets that is hidden from most of society. Le Carré may in fact be only interested in telling a good story, with a solid beginning, a captivating middle, and a strong ending. But ultimately, and perhaps unknowingly, or unwillingly, his stories reveal to us our own moral structures and allow us to examine our grey areas, thus making his spy novels the stories of ourselves. 


\section{WORKS CITED}

"The Agony and the Ecstasy: The Marriage of George and Ann Smiley." The Alphabetician. WordPress.com, 05 Apr 2012. Web. 9 Aug. 2013.

$<$ http://thealphabetician.wordpress.com/2012/04/05/the-agony-and-the-ecstasy-themarriage-of-george-and-ann-smiley/>.

"The Psychology of Espionage: Contemporary Commentary." International Bulleting of Political Psychology. Vol 9, .NO. 6 (2000): n. page. Web. 1 Sep. 2013.

$<$ http://security.pr.erau.edu/read.php?kind=html\&article_volume=9\&article_issue=6\&art icle_title=The Psychology of Espionage: Contemporary Commentary>.

Aronoff, Myron. The Spy Novels of John le Carré: Balancing Ethics and Politics. New York: Palgrave, 2001. 15-38. eBook.

Beene, Lynn. John Le Carré. New York, N.Y: Twayne Publishers, 1992.

Bold, Alan (ed.), The Quest for Le Carré, London: Vision Press, 1988, 129-143.

Cobbs, John L. Understanding John Le Carré. Columbia, S.C: University of South Carolina, 1997. eBook.

Coyle, Gene. The Dream Merchant of Lisbon: The Game of Espionage. Xlibris, Corp.

Derrida, Jacques. "Aporias." Trans. Stanford: Stanford University Press, 1993. Web. 25 Feb. 2014.

Derrida, Jacques. Margins of Philosophy. Chicago: University of Chicago Press, 1982. Print.

Derrida, Jacques. Of Grammatology. Baltimore: Johns Hopkins University Press, 1976. Print.

Derrida, Jacques, Alan Bass, and Henri Ronse. Positions. Chicago: University of Chicago Press, 1981. Print.

Dooley, Mark, and Liam Kavanagh. The Philosophy of Derrida. Montreal: McGill Queen's University Press, 2007. Print.

East, Andy. The Cold War File. Metuchen, N.J: Scarecrow Press, 1983. Print

Falcoff, Mark. Panama's Canal: What Happens When the United States Gives a Small Country What It Wants. Washington, D.C: AEI Press, 1998. Print. 
Fingeroth, Danny. Superman on the Couch: What Superheroes Really Tell Us about Ourselves and Our Society. New York and London: Continuum, 2005.

Fisher, Mark. “The Smiley Factor.” Film Quarterly. Vol. 65, No. 2 (Winter 2011), pp. 37-42.

Fletcher, Katy. "Evolution of the Modern American Spy Novel.” Journal of Contemporary History. Vol. 22, No. 2, Intelligence Services During the Second World War (Apr., 1987), pp. 319-331 Published.

Foucault, Michel, Mauro Bertani, Alessandro Fontana, François Ewald, and David Macey. Society Must Be Defended: Lectures at the Collège De France, 1975-76. New York: Picador, 2003. Print.

King, Holly Beth, "Child's Play in John le Carré's Tinker, Tailor, Soldier, Spy", Harold Bloom (ed.), John le Carré. New York: Chelsea House, 1987, 87 - 92.

Le Carré, John. "A Brief History of George Smiley by John Le Carré: The first appearance of John Le Carré's wily grey eminence: the first chapter of the first Smiley novel, Call for the Dead." Guardian [London, UK] 22 May 2009, Books.

Le Carré, John. A Murder of Quality. New York: Signet, 1964.

Le Carré, John. "Conversations with John Le Carré." Trans. Jackson: Univ. Press of Mississippi, 2004. Print.

Le Carré John. The Spy Who Came in from the Cold. New York: Coward-McCann, 1964.

Le Carré, John. The Tailor of Panama. New York: Ballantine Books, 1996.

Le Carré John. Tinker, Tailor, Soldier, Spy. New York: Knopf; [distributed by Random House, 1974.

Locke, Richard. "The Spy Who Spied on Spies." New York Times [New York] 30 Jun 1974, Books. Web. 31 Aug. 2013.

<http://www.nytimes.com/books/99/03/21/specials/lecarre-tinker.html>.

Masters, Anthony. Literary Agents: The Novelist As Spy. Oxford: B. Blackwell, 1987.

Navarro, Joe. Spies Among Us: Why Spies, Why Now? Published on July 19, 2010 by Joe Navarro, M.A. in Spycatcher.

Parker, James. "The Anti-James Bond." Atlantic. 23 Oct 2011: n. page. Web. 9 Aug. 2013. <http://www.theatlantic.com/magazine/archive/2011/12/the-antijamesbond/308708/>. 
Price, Matthew. "The Man Who Was George Smiley: The Life of John Bingham." National. 23 Mar 2013: n. page. Web. 9 Aug. 2013.

<http://www.pricewrites.com/articles/2013/05/the_man_who_was_smiley>

Rutherford, Andrew, The Literature of War: Five Studies in Heroic Virtue, London: Macmillan, 1978.

Sauerberg, Lars Ole, Secret Agents in Fiction: Ian Fleming, John le Carré and Len Deighton, London: Macmillan, 1984.

Schwartz, Janet. "Exploring the Mind of a Spy." Forensic Examiner. Spring (2007): 67 68. Print.

Stanchfield, John B. “The Peril of Espionage.” The North American Review. Vol. 203, No. 727 (Jun., 1916), pp. 830-840.

Steinberg, Alan. "Designed to Spy: The Evolutionary Psychology of Espionage." Paper presented at the annual meeting of the International Society of Political Psychology, Classical Chinese Garden, Portland, Oregon USA, 2012-06-23. http://www.allacademic.com/meta/p204557.

Stone, L. A. (1989). “On the Psychological Makeup of a Spy.” Forensic Report. Vol. 2, $215-221$.

Tayler, Christopher (25 January 2007). "Belgravia Cockney." London Review of Books (London: LRB) 29 (2): 13-14. ISSN 0260-9592. Retrieved 19 February 2014.

Web. 9 Aug. 2013. <http://www.theguardian.com/books/2009/may/22/le-carre-call-forthe-dead>.

Weiner, Tim. “How to Make a Spy.” Foreign Policy, No. 162 (Sep. - Oct., 2007), pp. 4448. 